\title{
Portfolio Managers on the Colombian Open-End Mutual Fund Industry: Performance, downside risk and persistence *
}

\author{
Administradores de Fondos de Inversión Colectiva en Colombia: desempeño, riesgo y persistencia \\ Administradores de fundos de investimento coletivo na Colômbia: desempenho, risco e persistência
}

\author{
Fredy Alexander Pulga Vivas ${ }^{a}$ \\ Universidad de la Sabana, Colombia \\ fredy.pulga@unisabana.edu.co \\ ORCID: http://orcid.org/0000-0003-0691-3698 \\ Maria Teresa Macías Joven \\ Universidad de la Sabana, Colombia \\ ORCID: http://orcid.org/0000-0002-7531-6785
}

DOI: https://doi.org/10.11144/Javeriana.cao32-59.pmco Redalyc: http://www.redalyc.org/articulo.oa? $\mathrm{id}=$ cuadernoss 20561244006

Date received: 09/05/2018

Date accepted: 31/10/2019

\begin{abstract}
:
This study explores whether Colombian mutual funds deliver abnormal risk-adjusted returns and delves on their persistence. Through traditional and downside risk measures based on Modern Portfolio Theory and Lower Partial Moments, this article evaluates the performance of 146 mutual funds categorized by investment type and fund manager. This assessment suggests that mutual funds underperform the market and deliver real returns. Similarly, bond funds underperform equity funds, and investment trusts underperform brokerage firms as managers. Furthermore, bond funds and funds managed by investment trusts exhibit shortterm performance persistence. These results suggest that investors may pursue passive investment strategies, and that they must analyze past performance to invest in the short-term.
\end{abstract}

JEL Codes: G11, G14, G23

Keywords: Mutual funds, fund performance, fund managers, downside risk, performance persistence.

\section{Resumen:}

Este estudio analiza si los FIC en Colombia ofrecen rendimientos ajustados por riesgo mayores al mercado y su persistencia. Evaluamos el desempeño de 146 FICs, por tipo de inversión y de administrador, utilizando la Teoría Moderna de Portafolios y "Momentos Parciales Inferiores". En general, los FICs ofrecen rendimientos reales inferiores a los del mercado. Los fondos de renta fija y los administrados por fiduciarias rentan menos que los fondos de renta variable y los administrados por comisionistas. Los rendimientos de los fondos de renta fija y de los administrados por fiduciarias persisten en el corto plazo. Los inversionistas deben seguir estrategias pasivas de inversión, y deben analizar el comportamiento pasado de los retornos para invertir en el corto plazo.

Códigos JEL: G11, G14, G23

Palabras clave: Fondos de Inversión Colectiva, rendimiento del fondo, administradores de los fondos, riesgo, desempeño, persistencia.

\section{Resumo:}

Este estudo analisa se os FICs da Colômbia oferecem retornos ajustados ao risco maiores que o mercado e sua persistência. Avaliamos o desempenho de 146 FICs, por tipo de investimento e administrador, usando a Teoria Moderna de Portfólios e "Momentos Parciais Inferiores". Em geral, as FICs oferecem retornos reais abaixo dos do mercado. Os fundos de renda fixa e os administrados por fiduciários alugam menos do que os fundos de ações e os administrados por agentes de comissão. Os rendimentos dos fundos de renda fixa e os administrados por fiduciários persistem no curto prazo. Os investidores devem seguir estratégias de investimento passivo e devem analisar o desempenho passado dos retornos para investir no curto prazo.

Códigos JEL: G11, G14, G23

Palavras-chave: Fundos de investimento coletivo, desempenho de fundos, gestores de fundos, risco, desempenho, persistência.

\section{Author notes}




\section{INTRODUCTION}

Over 1.5 million individuals invested in Colombian mutual funds, FICs (acronym in Spanish: Fondo de Inversión Colectiva), in 2016. The net worth managed in mutual funds accounted roughly for $7.7 \%$ of the national Gross Domestic Product. During the previous ten years, investors in FICs tripled and the value of the assets under management doubled as a fraction of the GDP. ${ }^{1}$

Despite the growing importance of the Colombian mutual fund industry, financial information on FICs is incomplete and fragmented (Ramírez, 2012; Monsalve \& Arango, 2016) despite the efforts of the regulator to encourage fund administrators to disclose the market value and the composition of the portfolios under management, their net asset values -NAV's-, and fees. In addition, the Superintendencia Financiera de Colombia -SFC- inquires managers to inform about daily fund returns as performance measure. Nonetheless, there is no obligation for fund managers to release risk data on FICs, thus there is no public information on risk-adjusted fund returns.

Such information is relevant for any investor to evaluate fund performance. Any investor must be able to assess fund returns regarding risk, fund performance relative to their peers, and whether a mutual fund (manager) is adding value in relation to her investment objectives.

Analyzing fund performance from an academic perspective ultimately delves on market efficiency (Fama, 1970) by assessing the managerial ability to consistently generate abnormal returns concerning the investment objectives of investors and the market. Our main objective is, therefore, to determine empirically whether Colombian mutual funds deliver abnormal risk-adjusted returns and if their ability persists.

The literature on FICs performance in Colombia is scarce. Most of these studies test the Efficient Market Hypothesis -EMH-, by comparing the risk-adjusted returns between any optimized investment strategy to a market portfolio, usually represented by an index or a benchmark. A limitation to this approach is the assumptions and the model used to optimize portfolios that may not be feasible in practice. Actually, these studies focus on the performance of theoretical portfolios versus a benchmark, thus they do not directly observe the performance of mutual funds.

On the one hand, this research shows that investors may take advantage of inefficiencies in the Colombian stock market by constructing portfolios that yield higher risk-adjusted returns relative to the benchmark. In this context, Medina and Echeverri (1993) provide evidence on the inefficiency of the market portfolio from 1979 to 1981, and 1990 to 1992, once they compare the performance of the market index with a set of optimized portfolios (Markowitz, 1952). More recently, Contreras, Stein, and Vecino (2015) find evidence on market inefficiency by analyzing the performance of twelve equity portfolios which maximize the Sharpe ratio from 2007 to 2012 . These portfolios outperform the market on the final value of the investment, returns and risk.

On the other hand, investors are indifferent to execute active or passive investment strategies. Such is the case of Dubova (2005), who finds no conclusive results neither on the dominance of the market portfolio nor on any optimized portfolio based on risk-adjusted returns, once she compares the performance of five optimized portfolios through the Capital Asset Pricing Model -CAPM-, and the index from 1993 to 2003.

Other studies test the EMH by evaluating the performance of managed portfolios through an asset pricing model. Such method allows for the direct assessment of mutual funds risk-adjusted returns in relation to the market, and whether these funds add value to investors. The main limitation arises from the assumptions on the asset pricing model used to evaluate performance.

In this context, investors are better off by investing passively. The results on active management for five equity funds (Piedrahita, 2012), through regression analysis on the CAPM and a Three Factor Model (Fama \& French, 1993), ${ }^{2}$ show that mutual funds exhibit negative and significant alphas, and declining Sharpe and Information ratios. Similarly, on a sample of 73 equity funds, Monsalve and Arango (2016) estimate 
Jensen's alphas through least squares and quantile regressions, and find that 22 funds exhibit significant alphas, of which four of them are positive, and present evidence on significant alphas for 43 funds, of which one is positive, respectively. The findings of Piedrahita (2012), and Monsalve and Arango (2016) validate market efficiency, since mutual funds do not outperform the stock market, and destroy value relative to their benchmarks.

This perspective to analyzing mutual funds highlights the potential of implementing a set of riskadjusted measures to evaluate the relative performance among funds and a benchmark. Furthermore, it allows to assess whether an investor may pursue active or passive investment strategies. Thus, such theoretical and empirical approach aligns the perspective of our investigation.

While previous studies tackle fund performance on the theoretical grounds of modern portfolio theory -MPT- we aim to ease the assumptions of normality and stationarity of fund returns by implementing downside risk-adjusted measures based on the third order stochastic dominance rule through lower partial moments -LPM- (Bawa, 1975; Bawa \& Lindenberg, 1977. One of the main advantages of such methodology is the capability to define risk on the ability of the manager to fulfill the investment goals of the investor (Sortino \& van der Meer, 1991, thus we also consider the failure of achieving such objectives as a part of evaluating fund performance. Furthermore, we analyze performance over time to determine whether mutual funds are able to consistently deliver superior returns (Goetzmann \& Ibbotson, 1994; Malkiel, 1995, or to accomplish the investment objectives of investors.

To this end, we assess the performance of 146 mutual funds divided into two categories. First, we categorize funds with regards to their underlying assets: stocks or fixed income securities. ${ }^{3}$ Second, we classify mutual funds relative to the manager, this is brokerage firms or investment trusts. To the best of our knowledge, this is the first study that analyzes the relative performance of funds and its persistence for this set of characteristics in the Colombian mutual fund industry.

In addition to this introduction, the paper is organized as follows: In the first section we provide the theoretical background on our MPT and LPM performance measures. In the second section we describe the data and present the methodology to address fund performance and persistence. We analyze fund performance through risk-adjusted measures and delve into the "hot hand phenomenon" in the third section. Finally, the conclusions are presented.

\section{A REVIEW ON PORTFOLIO PERFORMANCE AND DOWN-SIDE RISK}

\section{Traditional performance measures}

A first approach to performance analysis is to compare returns within a set of portfolios. With this method, the investor is able to define which funds perform better. Nevertheless, returns alone are not useful for evaluating portfolios: Positive large returns are not evidence of a skillful manager whose aim is to achieve returns above a benchmark (Grinold \& Kahn, 2000, or the profit target of an investment plan. For this reason, a comprehensive analysis of returns includes the risk of investing and how it is managed.

With the early works of Markowitz (1952, the models of equilibrium in capital markets such as the CAPM, developed by Treynor (1961, Sharpe (1964, Lintner (1965 and Mossin (1966, and the EMH (Fama, 1970),researchers focused on testing efficiency on financial markets and, as a consequence, on portfolio analysis based on risk-adjusted returns. Adjusting returns for risk allows investors to rank portfolios, such that the best performer is the fund that exhibits the highest risk-adjusted return. Moreover, it is useful for assessing fund performance compared to a benchmark portfolio, and to distinguish skillful managers. ${ }^{4}$ 
Blume, Crocket, \& Friend (1970) introduced a cross-sectional comparison between the returns of mutual funds and randomly generated portfolios with similar risk profiles. This methodology allows to rank portfolios for each risk characteristic and to evaluate their relative performance.

Under the CAPM framework, Treynor (1965) developed a return-to-risk measure to assess fund performance. The Treynor ratio compares the return in excess of the portfolios to their systematic risk, $\beta$, assuming that investors hold well diversified portfolios. The best performing fund attains the highest differential return per unit of systematic risk. Furthermore, an efficient portfolio exhibits the same Treynor ratio as the market portfolio, thus it also serves as the baseline for analyzing over or underperformance relative to a benchmark, and market efficiency.

Similarly, Sharpe (1966) developed a reward-to-variability ratio to compare funds excess returns to total risk measured by the standard deviation of fund returns. In a similar approach to Sharpe (1966), Modigliani and Modigliani (1997) introduced the $M^{2}$ measure as a differential return between any investment fund and the market portfolio for the same level of risk. ${ }^{5}$ The Modigliani-squared measure ranking is equivalent to that produced by the Sharpe ratio.

Jensen (1968) presented an absolute performance measure founded on the CAPM. Allowing the possibility of skillful managers, he introduced an unconstrained regression between the risk premium on any security or portfolio and the market premium. The constant in the regression measures fund performance as the ability of the manager to earn returns above the market premium for any level of systematic risk; correspondingly, it also captures under performance.

\section{Lower partial moments}

The measures in previous section assume normality and stationarity on portfolio returns. In practice, return distributions are not symmetrical and their statistical parameters change over time. Furthermore, these performance measures can be manipulated through "informationless trading" by simulating stationarity on returns or smoothing variance. Bookstaber and Clarke (1985), Goetzmann, Ingersoll, \& Ivkovich (2000), Lhabitant (2000), Ferson and Siegel (2001) and more recently Goetzmann, Ingersoll, Spiegel, \& Welch (2007) demonstrated how the Sharpe ratio is improved in portfolios that use derivatives on the market portfolio or the assets within the managed portfolio, and that implement dynamic allocation strategies between evaluation periods.

To deal with the assumptions on the return distributions to assess fund performance, Bawa (1975) demonstrated that the mean-lower partial variance ${ }^{6}$ is a suitable approximation to the Third Order Stochastic Dominance rule, which is the optimal criteria for selecting portfolios for any investor who exhibits decreasing absolute risk aversion, independent of the shape of the distribution of returns. Under this framework, Fishburn (1977) presented a mean-risk dominance model -the a-t model, for selecting portfolios. Fishburn (1977) defined uncertainty as the probability of not achieving a minimum return, and risk is measured by a "probability-weighted function of deviations below a specific target return". 7

Based on Fishburn's ideas, Sortino and van der Meer (1991) compared the performance on optimized portfolios through the traditional CAPM and a downside risk model. For the latter, they defined risk as the probable negative outcomes when the return of the portfolio falls below a minimum required return, the DTR. From this examination, Sortino and Price (1994) introduced two performance measures: the Sortino ratio and the Fouse index.

The Sortino ratio measures performance in a downside variance model: whereas the Sharpe ratio uses the mean as the target return and variance as risk, the Sortino Ratio uses the DTR and downside deviation respectively. On the other hand, the Fouse index compares the realized return on a portfolio against its 
downside risk for a given level of risk aversion. It is a net return after accounting for downside deviation and the risk attitude of the investor.

More recently, Sortino et al. (1999) presented the Upside Potential Ratio, UPR, to assess fund performance. The UPR compares the success of achieving the investment objectives of a portfolio to the risk of not fulfilling them. In this context, the main objective of the manager of the fund is "to maximize the expected return above the DTR, subject to the risk of falling below the DTR" (Sortino et al., 1999). The UPR is "a measure of the inherent risk the manager is taking of not achieving the investor's DTR relative to the potential of exceeding that desired return" (Sortino, van der Meer, Plantinga, \& Kuan, 2010).

\section{DATA AND METHODOLOGY}

\section{The sample}

Our data set includes daily Net Asset Values, NAVs, for 146 open-end mutual funds from March 31, 1995 to June 30, 2016, expressed in Colombian pesos, COP. We restrict our analysis to funds domiciled in Colombia that invest in domestic securities, either equity or fixed income. Furthermore, the funds in the sample are required to exhibit at least one and a half years of daily pricing data. The sample includes active and liquidated funds to address survivorship bias. We collected funds prospectus, inception and liquidation dates, asset al-locations and other descriptive data from the SFC, and relevant market data from Bloomberg and Reuters.

We classified funds by investment type, taking into account that self-declared equity funds allocate a portion of their investments into short-term fixed income securities to provide liquidity to their investors. Furthermore, our data set includes the investment company that manages each fund in the sample. Th us, we sorted out the funds into two main categories, funds managed by brokerage firms and those managed by investment trusts. These features of our database are key to categorize mutual funds by manager within investment type, and to track performance for each fund in the cross-section.

As reported in Table 1-Panel A, from the 146 funds in the data set, 67 were invested in domestic equity and 79 in fixed income securities. By the end of the period, there were 117 active funds. The median age of the funds in the sample was 6.31 years. The overall age ranged from 1.83 to 21.27 years. Fixed income funds displayed a greater median age, 7.85 years, relative to equity funds, which median age was 4.67 years. These figures are consistent with the trend of the size of the bond and equity markets in Colombia during the sample period. ${ }^{8}$

Table 1-Panel B reports on the distribution of mutual funds by manager. Brokerage firms managed 85 funds, with a median age of 5.08 years. Sixty-five of these funds were active at the end of the period. At the same time, investment trusts managed 61 mutual funds, with a median age of 11 years. From these funds, 52 were still active by June 2016. Table 1-Panels C and D display the distribution of mutual funds by manager within investment type. In the equity side, 81 percent of the funds were managed by brokerage fi rms, whereas investment trusts managed 61 percent of fixed income funds. 
TABLE 1

Mutual funds by investment type and fund manager

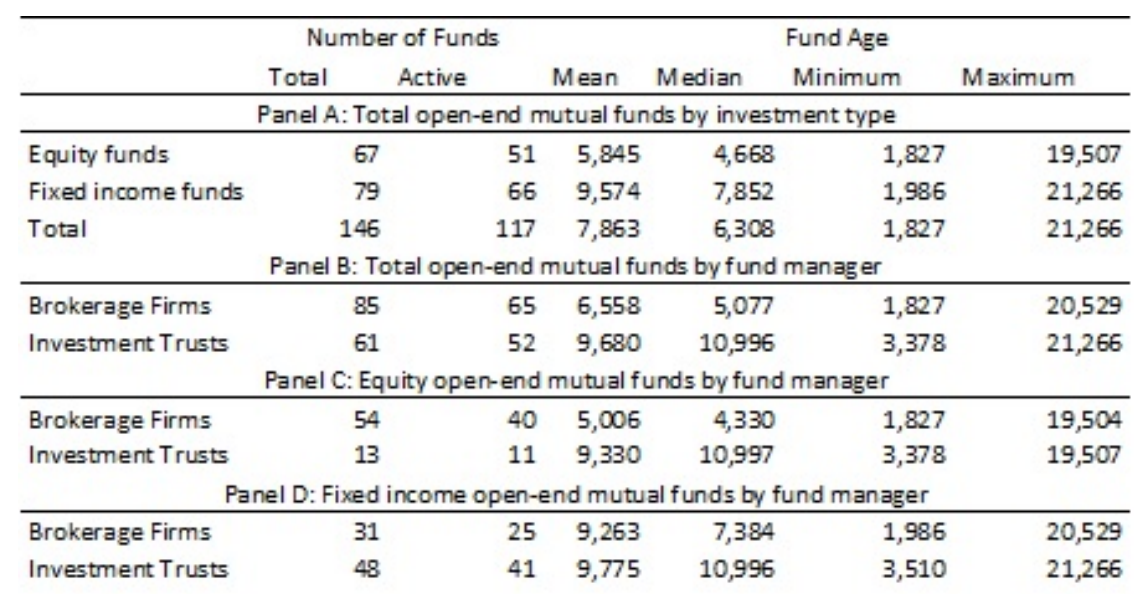

Note: This table reports the distribution of mutual funds by investment type and fund manager. The sample includes active and liquidated funds from March 31, 1995 to June 30, 2016. Fund age accounts for the presence of the funds in the data set and is expressed in years. Panel A exhibits the distribution of mutual funds by investment type, i.e. equity or fixed income. Panel B exhibits the distribution of mutual funds by fund manager, brokerage firms (BF) or investment trusts (IT). Panel C displays the distribution of equity mutual funds by fund manager. Panel $\mathrm{D}$ presents the distribution of fixed income mutual funds by fund manager. Source: Own elaboration.

Inasmuch as the investment set of the mutual funds includes Colombian securities, the benchmarks for the equity funds used in our analysis are the MSCI Emerging Markets Index for Colombia, the IGBC and the COLCAP index. The market reference for the fixed income funds is the COLTES index. The risk-free rate in COP is the overnight Interbank Offered Rate, TIB, provided by the Central Bank, and the Colombian consumer inflation index is the IPC.

Table 2 reports summarized descriptive statistics of daily continuously compounded returns on mutual funds and their respective benchmarks. Since re-turns on funds were calculated from their NAVs, these are net of management and administration expenses, thus the forthcoming analysis is on net performance. As detailed in Table 2-Panel A, the mean and median daily returns for the funds in the sample were positive, and fixed income funds displayed higher mean and median returns than equity funds. The greater range of daily returns occurred on equity funds, which also exhibited higher standard deviation.

From the managers perspective, funds managed by brokerage firms exhibited lower mean and median returns, larger standard deviations and a greater negative skewness, compared to investment trusts funds, as presented in Table 2-Panel B. These statistics hold for equity and fixed income markets, as shown in Table 2-Panels C and D, except for the mean and median returns of mutual funds managed by brokerage firms, which were larger in the bond market. An interesting fact of fund returns is that, on average, they are negative skewed, thus the aggregate information on return distributions suggests that neither of the time series of returns are symmetric. 
TABLE 2

Returns statistics on mutual funds and benchmarks

\begin{tabular}{|c|c|c|c|c|c|c|c|}
\hline & $\begin{array}{r}\text { Observations } \\
\text { Panel A }\end{array}$ & $\begin{array}{l}\text { Mean } \\
\text { Total } n\end{array}$ & $\begin{array}{l}\text { Median } \\
\text { nutual fu }\end{array}$ & $\begin{array}{l}\text { Minimum } \\
\text { ds by inve }\end{array}$ & $\begin{array}{l}\text { Maximum } \\
\text { tment type }\end{array}$ & $\begin{array}{c}\text { S. } \\
\text { Deviation }\end{array}$ & Skewness \\
\hline \multirow{4}{*}{$\begin{array}{l}\text { Equity Funds } \\
\text { Fixed Income } \\
\text { Funds } \\
\text { Total }\end{array}$} & 110.449 & 0,008 & 0,004 & $-24,906$ & 22,313 & 0,884 & $-0,334$ \\
\hline & 202.037 & 0,020 & 0,015 & $-13,657$ & 13,769 & 0,132 & $-1,160$ \\
\hline & 312.486 & 0,014 & 0,010 & $-24,906$ & 22,313 & 0,477 & $-0,781$ \\
\hline & \multicolumn{7}{|c|}{ Panel B: Total mutual funds by fund manager } \\
\hline \multirow{2}{*}{$\begin{array}{l}\text { Brokerage } \\
\text { Firms } \\
\text { Investment } \\
\text { Trusts } \\
\end{array}$} & 158.716 & 0,011 & 0,008 & $-24,906$ & 22,313 & 0,698 & $-1,160$ \\
\hline & 153.770 & 0,018 & 0,013 & $-13,331$ & 16,813 & 0,170 & $-0,252$ \\
\hline \multicolumn{8}{|c|}{ Panel C: Equitymutual funds by fund manager } \\
\hline \multirow{2}{*}{$\begin{array}{l}\text { Brokerage } \\
\text { Firms } \\
\text { Investment } \\
\text { Trusts } \\
\end{array}$} & 79.346 & 0,006 & 0,003 & $-24,906$ & 22,313 & 0,995 & $-0,572$ \\
\hline & 31.103 & 0,016 & 0,009 & $-13,331$ & 16,813 & 0,426 & 0,655 \\
\hline \multicolumn{8}{|c|}{ Panel D: Fixed income mutual funds by fund manager } \\
\hline \multirow{2}{*}{$\begin{array}{l}\text { Brokerage } \\
\text { Firms } \\
\text { Investment } \\
\text { Trusts } \\
\end{array}$} & 79.370 & 0,021 & 0,015 & $-13,657$ & 13,769 & 0,182 & $-2,185$ \\
\hline & 122.667 & 0,019 & 0,014 & $-10,878$ & 10,935 & 0,100 & $-0,498$ \\
\hline \multicolumn{8}{|c|}{ Panel E: Equity and fixed income benchmarks } \\
\hline $\begin{array}{l}\text { MSCI EM } \\
\text { Index }\end{array}$ & 5.545 & 0,047 & 0,000 & $-11,993$ & 16,703 & 1,313 & 0,175 \\
\hline IGBC Index & 3.912 & 0,058 & 0,020 & $-11,052$ & 14,688 & 1,269 & $-0,172$ \\
\hline $\begin{array}{l}\text { COLCAP } \\
\text { Index }\end{array}$ & 3.643 & 0,006 & 0,004 & $-13,254$ & 15,126 & 1,281 & $-0,098$ \\
\hline $\begin{array}{l}\text { COLTES } \\
\text { Index }\end{array}$ & 2.218 & 0,034 & 0,043 & $-1,712$ & 1,488 & 0,262 & $-0,516$ \\
\hline
\end{tabular}

Note: This table reports summarized descriptive statistics of daily continuously compounded returns on 146 mutual funds by investment type and fund manager, and their respective market benchmarks. Daily returns are calculated as the change in NAV's and index values respectively. Returns are expressed in percentages. For funds, statistical data is presented as the equally-weighted average of each measure. Panel A displays mutual funds returns statistics by investment type and panel $B$ exhibits mutual funds returns statistics by fund manager. Panel $C$ and $D$ present mutual fund statistics by fund manager within investment type, equity and fixed income respectively. Panel E reports summary statistics for index benchmarks.

Source: Own elaboration.

Detailed figures on the asymmetry of return distributions showed that returns on 88 mutual funds were negatively skewed; in addition, returns on 58 funds displayed positive skewness. To further investigate whether the time series of returns of the mutual funds and the indexes exhibited normality, to evaluate the relevance of applying LPM measures to assess fund performance, we performed the Shapiro-Wilk test on mutual fund returns. The results of the test disclosed that none of the time series of returns followed a normal distribution. $^{9}$

\section{Risk-adjusted measures}

To assess the performance of mutual funds in Colombia, we started by using a set of measures derived from MPT. Founded on the CAPM, we first computed the Treynor ratio (Treynor, 1965) of each fund $p$, as:

$$
T R_{p}=\frac{\overline{R_{p}}-\overline{R_{F}}}{\beta_{p}}
$$

where $\overline{R_{p}}$ is the realized average return of fund $p, \overline{R_{F}}$ is the average risk-free rate and $\beta_{\mathrm{p}}{ }^{10}$ is a measure of systematic risk of fund $p$. A good performing fund displays a higher Treynor ratio as long as the manager achieves either greater returns in excess or mitigates systematic risk. Similarly, we computed the Sharpe ratio of each fund (Sharpe, 1966) as the ratio between the risk premium and the realized standard deviation of the returns of fund $p, \sigma_{\mathrm{p}}$ : 


$$
S R_{p}=\frac{\overline{R_{p}}-\overline{R_{F}}}{\sigma_{p}}
$$

An investor is interested in the fund that exhibits the highest Sharpe Ratio. It is attained by achieving high returns in excess of the risk-free rate or by reducing the standard deviation of its returns, i.e. its risk.

We also computed $M^{2}$ the measure presented by Modigliani and Modigliani (1997). First, we estimated risk-adjusted returns per fund, $R A P_{\mathrm{p}}$, as follows:

$$
R A P_{p}=\frac{\overline{R_{p}}-\overline{R_{F}}}{\sigma_{p}} \sigma_{M}+\overline{R_{F}}
$$

where $\sigma_{\mathrm{M}}$ is the standard deviation of the respective benchmark return for each fund in the sample. In addition, we calculated the difference between the risk-adjusted return of a fund, $R A P_{\mathrm{p}}$, and the realized average market return, $\overline{R_{M}}$, to attain the $M^{2}$ measure per fund. The $M^{2}$ measure is a differential return that compares the performance of the fund relative to the market, thus the greater the measure the better the fund:

$$
M_{p}^{2}=R A P_{p}-\overline{R_{M}}
$$

With the aim to assess the skills of a manager we computed our last traditional performance measure, Jensen's alpha (Jensen, 1968). Jensen's alpha, is the average realized return of fund $p$ over the equilibrium return predicted by the CAPM for identical betas:

$$
\alpha_{p}=\overline{R_{p}}-\left[\overline{R_{F}}+\beta_{p}\left(\overline{R_{M}}-\overline{R_{F}}\right)\right]
$$

Since alpha is a differential return on the CAPM, it is estimated with a time series regression of funds excess returns against benchmark excess returns over the risk-free rate:

$$
R_{p, t}-R_{F, t}=\alpha_{p}+\beta_{p}\left(R_{M, t}-R_{F, t}\right)+e_{p, t}
$$

Where $\alpha_{\mathrm{p}}$ is the estimation of Jensen's performance measure for fund $p, \beta_{\mathrm{p}}$ is its measure of non-diversifiable risk, $R_{\mathrm{M}}$ is the realized market return, $R_{\mathrm{F}}$ is the risk-free rate and ep is the error term of the regression. As long as $\alpha_{\mathrm{p}}$ is positive and statistically significant, the manager of the fund displays investment skills, since she provides returns in excess of the market premium for any level of systematic risk, thus the greater the alpha the better the fund. 


\section{Downside risk and value added}

In addition to our traditional measures of fund performance, we computed a set of indicators that account for the asymmetry of the return distributions, and the deviations of the returns of each fund with regard to their strategic investment objective, the so called DTR.

Based on the LPM methodology, we first defined $p\left(R_{\mathrm{p}}\right)$ as the discrete probability function of the returns of fund $p$. To this end, let us define the set of fund returns greater than its DTR:

$$
R_{p}^{+}=\left\{R_{p}: R_{p}>T_{p}\right\}
$$

Then, we estimated the upside probability of each fund, $U P_{\mathrm{p}}$, as the probability that the return of the fund, $R_{\mathrm{p}}$, surpasses its DTR, $T_{\mathrm{p}}$. The higher the upside probability of the fund the greater the likelihood of the fund to achieve returns above its DTR:

$$
U P_{p}=\sum_{R_{p} \in R_{p}^{+}} p\left(R_{p}\right)
$$

Similarly, we computed the upside potential of each fund, $U P O_{\mathrm{p}}$, as the average excess return of fund $p$ over its DTR, when the return of the fund is higher than its strategic target:

$$
U P O_{p}=\sum_{R_{p} \in R_{p}^{+}}\left(R_{p}-T_{p}\right) \cdot p\left(R_{p}\right)
$$

Furthermore, we define the set of negative deviations of the returns of a fund with regard to its strategic target:

$$
R_{p}^{-}=\left\{R_{p}: R_{p}<T_{p}\right\}
$$

With this set of returns, we estimate the downside risk of fund $p, \delta_{\mathrm{p}}$, as a measure of the volatility of the returns below the DTR. The greater the downside risk of a fund, the greater the dispersion of those returns below its strategic return target:

$$
\delta_{p}=\sqrt{\sum_{R_{p} \in R_{p}^{-}}\left(R_{p}-T_{p}\right)^{2} \cdot p\left(R_{p}\right)}
$$

We performed an alternative calculation for "downside risk", $\delta_{p}^{a}$, by considering the mean of the absolute value of the negative deviations of the return of fund $p, R_{\mathrm{p}}$, with regards to its DTR: 


$$
\delta_{p}^{a}=\sum_{R_{p} \in R_{p}^{-}}\left|R_{p}-T_{p}\right| \cdot p\left(R_{p}\right)
$$

In the LPM framework, the performance measures adjust fund returns for downside risk and its target return. Such is the case of our first fund performance measure, the Sortino ratio (Sortino \& Price, 1994). We computed the Sortino ratio for fund $p, S_{\mathrm{p}}$, by comparing the average return of fund $p$ in excess of its DTR to its downside risk. A good performing portfolio has a greater Sortino ratio as long as it exhibits a larger return per unit of downside risk:

$$
S_{p}=\frac{\overline{R_{p}}-\overline{T_{p}}}{\delta_{p}}
$$

Likewise, we calculated the Fouse index, $F I_{\mathrm{p}}$, as "the net return earned after subtracting the required risk premium" (Sortino \& Price, 1994), which is computed as the product of a risk aversion parameter, $A,{ }^{11}$ and downside risk. The Fouse index is a differential return adjusted by downside risk, thus the larger the performance measure, the better the fund:

$$
F I_{p}=\overline{R_{p}}-A \cdot \delta_{p}^{2}
$$

We finally estimated the upside potential ratio of fund $p, U P R_{\mathrm{p}}$, defined as the ratio of the upside potential of a fund to its downside risk (Sortino et al., 1999). The upside potential ratio relates the average return in excess of the fund relative to its DTR with the risk of not achieving it, thus a good performing fund exhibits positive and larger values of $U P R_{\mathrm{p}}$ :

$$
U P R_{p}=\frac{U P O_{p}}{\delta_{p}}
$$

We computed the performance measures described in previous sections per fund, ${ }^{12}$ taking into account the time the funds were present in the data set, this is from the inception date until either the liquidation, or the final date of the sample period. Similarly, we estimated these indicators for the benchmarks. We further aggregated each performance measure based on our classification of funds by investment type and by manager and performed a non-parametric analysis through mean paired tests to assess average fund performance.

\section{Persistence}

To test for the presence of a "Hot Hand" phenomenon in the Colombian mutual fund industry, we followed the methodology of Goetzmann and Ibbotson (1994) and Malkiel (1995).

First, we divided the sample of fund returns over consecutive one-year periods. Then, we constructed twoway tables by defining winners (losers) as those funds that achieved risk-adjusted returns above (below) the 
median risk-adjusted return each year to present performance across time. Second, we tested for the null hypothesis of "no winning persistence" using a Chi-square statistic and the Z-Malkiel statistic, Z, ${ }^{13}$ as follows:

$$
Z=\left(\frac{(Y-n p)}{\sqrt{n p(1-p)}}\right)
$$

For a number of funds, , greater than 20, denotes a random variable of the number of funds that exhibit winning performance, and $p$ is the probability that a winner fund will achieve superior returns in the next period. We perfomed the tests on persistence for the funds in the sample and categorized by investment type and by manager.

\section{MARKETS, MANAGERS AND PERSISTENCE}

\section{Equity and bond funds}

In this section we assess the performance of mutual funds classified by investment type. First, we present the results using the MPT measures to examine performance with respect to the benchmarks. Second, we extend our analysis to the LPM indicators, thus we study fund performance in relation to the investment objectives of the funds.

Table 3 reports the non-parametric results of a mean paired test on performance for the mutual funds in the sample with respect to their benchmarks. At the individual level, a fund is understood to outperform its benchmark when it achieves a greater risk-adjusted measure compared to the one calculated for the market. Furthermore, in the case of the Sharpe ratio and Jensen's alpha, these measures must be statistically significant. As a group, mutual funds outperform the market when the difference between the average measures for the funds and the benchmark is positive and statistically significant.

As detailed in Table 3-Panel A, mutual funds underperform the market. According to the Sharpe ratio, the average excess return of the funds is 74 basis points lower than the market. Similarly, the $M^{2}$ measure reveals that, on average, risk-adjusted returns on funds are 2 basis points below benchmark returns. Likewise, there is no evidence of average managerial skill, ${ }^{14}$ as reported by alpha.

At the investment type level, equity mutual funds display different performance. As shown in Table 3Panel B, negative risk-adjusted returns calculated through the Sharpe ratio indicate that market and funds returns do not compensate risk. Nevertheless, equity funds returns exceed market returns on 20 basis points. Accordingly, the $M^{2}$ indicates that equity mutual funds out per-form the market by 3 basis points. On average, alpha indicates that there is no evidence of superior managerial skills. 
TABLE 3

Mutual fund performance

\begin{tabular}{|c|c|c|c|c|}
\hline & Treynor & Sharpe & $\mathrm{M} 2$ & Alpha \\
\hline \multicolumn{5}{|c|}{ Panel A: Total mutual funds } \\
\hline Fund Average & 0,841 & $-0,538$ & $-0,020$ & 0,000 \\
\hline Market Average & $-0,015$ & 0,205 & 0,000 & 0,000 \\
\hline Di? erence & 0,856 & $-0,743^{* * *}$ & $-0,020^{* *}$ & 0,000 \\
\hline t-statistic & 0,294 & 6,576 & $-2,578$ & $-0,037$ \\
\hline Number of out & 47 & 40 & 40 & 46 \\
\hline $\begin{array}{l}\text { perormers } \\
\text { Positive and statistically } \\
\text { significant }\end{array}$ & & 1 & & 2 \\
\hline Negative and & & 0 & & 29 \\
\hline \multicolumn{5}{|c|}{ Panel B: Equitymutual funds } \\
\hline Fund Average & 3,520 & $-0,232$ & 0,030 & 0,006 \\
\hline Market Average & $-0,069$ & $-0,432$ & 0,000 & 0,000 \\
\hline Di? erence & 3,589 & $0,201^{* * *}$ & $0,030^{* *}$ & 0,006 \\
\hline t-statistic & 0,567 & 2,716 & 2,271 & 0,775 \\
\hline $\begin{array}{l}\text { Number of out } \\
\text { performers }\end{array}$ & 33 & 37 & 37 & 31 \\
\hline $\begin{array}{l}\text { Positive and statistically } \\
\text { significant }\end{array}$ & & 1 & & 1 \\
\hline $\begin{array}{l}\text { Negative and } \\
\text { statistically significant }\end{array}$ & & 0 & & 5 \\
\hline \multicolumn{5}{|c|}{ Panel C: Fix ed Income mutual funds } \\
\hline Fund Average & $-1,432$ & $-0,798$ & $-0,063$ & $-0,005$ \\
\hline Market Average & 0,030 & 0,745 & 0,000 & 0,000 \\
\hline Di? erence & $-1,462^{* *}$ & $-1,543^{* * *}$ & $-0,063^{* * *}$ & $-0,005^{* * *}$ \\
\hline t-statistic & $-2,465$ & $-10,391$ & $-10,578$ & $-4,545$ \\
\hline $\begin{array}{l}\text { Number of out } \\
\text { performers }\end{array}$ & 14 & 3 & 3 & 15 \\
\hline $\begin{array}{l}\text { Positive and statistically } \\
\text { significant }\end{array}$ & & 0 & & 1 \\
\hline $\begin{array}{l}\text { Negative and } \\
\text { statistically significant }\end{array}$ & & 0 & & 24 \\
\hline
\end{tabular}

Notes: This table compares the performance of 146 mutual funds by investment type from March 31, 1995 to June 30, 2016 and two benchmarks: the MSCI index for the equity funds and the COLTES index for the fixed income funds. Panel A presents the overall performance of mutual funds. Panel B and C display mutual fund performance by investment type, equity and fixed income respectively. Figures are annualized. ${ }^{* * *} /{ }^{* *} /{ }^{*}$ indicate that with the paired t-test of means per measure, their difference is significantly different from zero at the $1 \% / 5 \% / 10 \%$ level. Source: Own elaboration.

In the bond market, the traditional measures are indicative of the overall under performance of mutual funds in relation to their benchmark. Table 3-Panel C reports that risk-adjusted returns of bond funds are 146 basis points lower than the benchmark according to the Treynor ratio. Furthermore, mutual funds display negative Sharpe ratios, and are below their market counterparts by 154 basis points. Likewise, bond funds underperform the market by 6 basis points for the same level of risk, as the $M^{2}$ measure indicates. A further examination of investment skill reveals that, on average, these funds destroy value to investors.

Table 4 reports the non-parametric results of the performance of 146 mutual funds by investment type, as assessed by downside risk measures. To perform the evaluation, three strategic return objectives were observed: ${ }^{15}$ a DTR equal to zero that allows us to analyze the failure of a fund to achieving positive returns; a DTR equals to the Colombian annual consumer inflation, IPC, which accounts for real returns in COP, and a DTR equal to the return of the respective benchmark, BMK, to evaluate performance relative to the market.

Table 4-Panel $\mathrm{A}$ indicate that the mutual funds in the sample and the benchmarks add value to investors, when the strategic investment objective of the investor is to achieve positive returns. Furthermore, mutual funds exhibit re-turns per unit of downside risk greater than the returns on the benchmarks as assessed trough the Sortino ratio, and the funds display a higher probability of attaining positive returns. Once we set the strategic investment return to annual consumer inflation, the funds and the indexes deliver positive adjusted returns. Nonetheless, the market achieves superior performance as measured by the Sortino and the Upside potential ratio. Firstly, mutual funds under per-form their benchmarks by 19 basis points; secondly, market indexes exhibit a higher probability of delivering returns above inflation per unit of downside deviation. We also analyze the case when the investment objective is to beat the market. The results indicate that funds under perform the benchmarks by 38 basis points as measured by the Sortino ratio.

Table 4-Panel B, reveals that equity funds generate positive risk-adjusted returns, in line with the Sortino ratio and the Fouse index when the $\mathrm{DTR}=0$. Furthermore, equity funds outperform the MSCI Index by 117 basis points, and 4 basis points when returns are adjusted to the appropriate risk premium, respectively. 
Pertaining to the ability of equity funds to produce returns above inflation, the Sortino ratio and the Fouse index are negative. Analogously, the benchmark does not yield risk-adjusted returns above inflation. Despite the fact that neither equity funds, nor the benchmark add value to investors when the investment objective is to achieve real returns, mutual funds outperform the market by 43 and 4 basis points as measured by the Sortino ratio and the Fouse index respectively. These figures are confirmed for a desired target return equal to the return of the benchmark. Downside risk measures reveal the dominance of equity funds as they deliver superior returns. In terms of the Sortino ratio and the Fouse index, funds outperform the market in 42 basis points, and 2 basis points when the risk premium is discounted. Notwithstanding, equity funds display a lower potential to produce returns above the investment objective when it is defined as either positive returns or real returns. The UPR indicates that, in the former case, the market exceeds the funds returns over the DTR in 43 basis points and, in the latter case, in 93 basis points.

TABLE 4

Downside risk measures on mutual fund performance

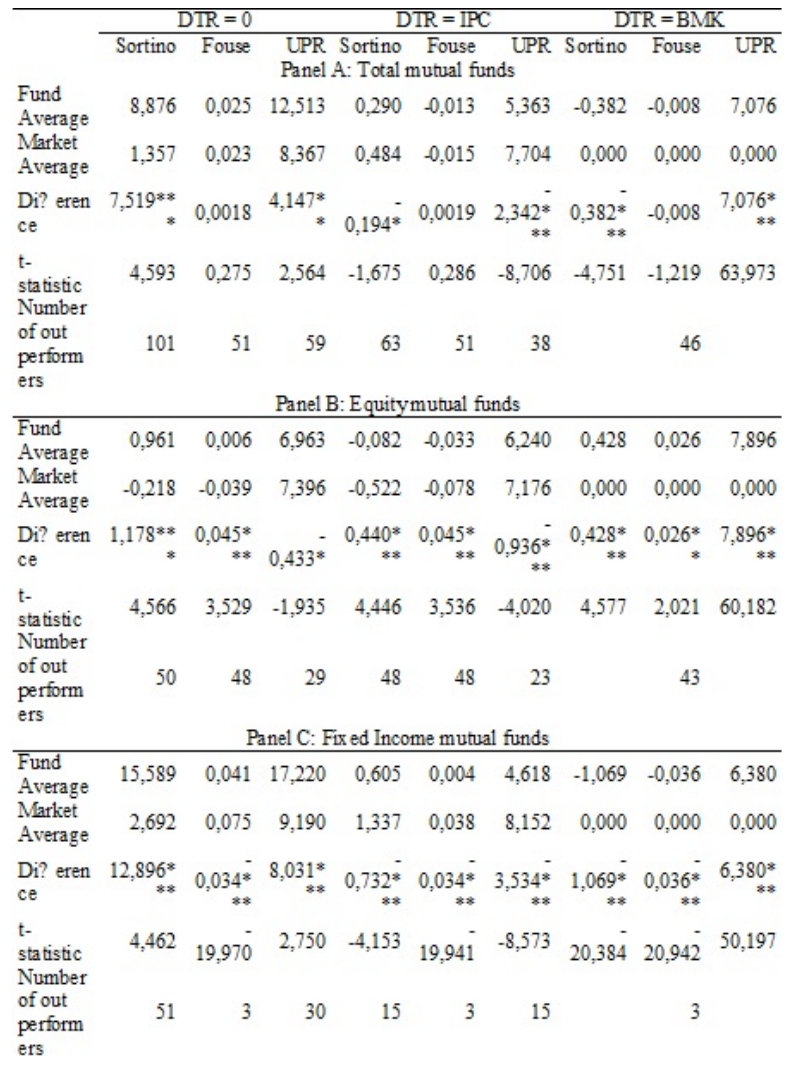

Notes: This table reports the performance of 146 mutual funds by investment type from March 31, 1995 to June 30, 2016, by means of the Sortino ratio, the Fouse index and the Upside potential ratio. Panel A presents the overall performance of mutual funds. Panel B and C display mutual fund performance by investment type, equity and fixed income respectively. To estimate downside risk measures, three strategic return objectives (DTR) were considered: 0; annual inflation (IPC), and the annual mean return of the benchmark (BMK). The benchmarks for calculations are the MSCI index for the equity funds and the COLTES index for the fixed income funds. The calculations are performed to both, funds and indexes. Figures are annualized. ${ }^{* * *} /{ }^{* *} /{ }^{*}$ indicate that with the paired $t$-test of means per measure, their difference is significantly different from zero at the $1 \% / 5 \% / 10 \%$ level.

Source: Own elaboration.

Table 4-Panel $\mathrm{C}$ reports that bond funds do add value to investors, for a $D T R=0$. In comparison to the market, there are mixed results: mutual funds outperform the benchmark as gauged by the Sortino ratio, in 128 percentage points, whereas the Fouse index indicates that bond funds under perform the benchmark by 3 basis points. When the investment objective is to achieve positive real returns, the Sortino ratio and the Fouse index are positive. In this case, bond funds underperform the market in 73 basis points and 3 basis points when risk is subtracted, respectively. With respect to the skills of the manager to generate superior returns, the downside risk measures confirm that mutual funds do not offer higher risk-adjusted returns compared 
with the benchmark. Specifically, bond funds risk-adjusted returns are 106 basis points lower in line with the Sortino ratio, and 3 basis points below the market as reported by the Fouse index. The potential of fixed income funds to produce returns above the strategic targets, per unit of downside deviation, is greater to the one observed by the market when the $D T R=0$. When the strategic investment objective is inflation, the likelihood of achieving returns above the DTR is greater for the benchmark.

\section{The managers}

In the previous section we documented the performance of mutual funds against their benchmarks. In this section we provide a cross-sectional evaluation of fund management. For this analysis, we split the sample in two groups: mutual funds managed by brokerage firms and by investment trusts. Furthermore, we take a closer look to the performance of each group by investment type. This analysis is twofold, we can observe the ability of the managers to outperform the market, and to gauge which group displays greater investment skills. For the latter, brokerage firms outperform investment trusts when the difference between the average measures between each group is positive and statistically significant. As in the previous section, we begin our analysis with the traditional performance assessment to further examine mutual funds in accordance with the downside risk measures.

Table 5-Panel A reports the performance of 146 mutual funds classified by investment manager. In line with the Sharpe ratio, neither brokerage firm nor investment trust funds generate positive risk-adjusted returns. Despite neither type of funds add value, brokerage firm funds outperform their peers by 42 basis points. The $M^{2}$ measure confirms this result. As a matter of fact, brokerage firm funds display positive riskadjusted returns, while investment trust funds exhibit negative returns, thus the former exceeds the latter by 6 basis points. Furthermore, alphas suggest that there is no statistically significant difference in the the average investment skills of the managers.

The relative performance of equity mutual funds is presented in Table 5-Panel B. Risk-adjusted returns are negative for both type of managers, as re-ported by the Sharpe ratio. The $M^{2}$ measure presents evidence on the underperformance of investment trusts in relation to brokerage firm funds. Risk-adjusted returns are higher for the latter in 7 basis points. Moreover, funds managed by brokerage firms outperform the market in 4 basis points, and in-vestment trusts yield 3 basis point below the benchmarks. Similarly, alphas on both managers disclose that there is no statistically significant difference in their investment skills as managers of equity mutual funds. 
TABLE 5

Fund manager performance

\begin{tabular}{|c|c|c|c|c|}
\hline & Treynor & Sharpe & $\mathrm{M}$ & Alpha \\
\hline \multicolumn{5}{|c|}{ Panel A: Total mutual funds } \\
\hline Brokerage Firms & 4,399 & $-0,360$ & 0,009 & 0,003 \\
\hline Investment Trusts & $-4,118$ & $-0,786$ & $-0,061$ & $-0,004$ \\
\hline Di? erence & 8,517 & $0,426^{* *}$ & $0,069 * * *$ & 0,007 \\
\hline t-statistic & 1,446 & 2,387 & 4,650 & 0,919 \\
\hline $\begin{array}{l}\text { Number of BF out } \\
\text { performers }\end{array}$ & 35 & 35 & 35 & 36 \\
\hline $\begin{array}{l}\text { Number of IT out } \\
\text { performers }\end{array}$ & 12 & 5 & 5 & 10 \\
\hline \multicolumn{5}{|c|}{ Panel B: Equitymutual funds } \\
\hline Brokerage Firms & 7,862 & $-0,206$ & 0,045 & 0,006 \\
\hline Investment Trusts & $-14,517$ & $-0,337$ & $-0,032$ & 0,005 \\
\hline Di? erence & 22,379 & 0,131 & $0,077^{* *}$ & 0,002 \\
\hline t-statistic & 1,410 & 0,919 & 2,384 & 0,077 \\
\hline $\begin{array}{l}\text { Number of BF out } \\
\text { performers }\end{array}$ & 28 & 34 & 34 & 27 \\
\hline $\begin{array}{l}\text { Number of IT out } \\
\text { performers }\end{array}$ & 5 & 3 & 3 & 4 \\
\hline \multicolumn{5}{|c|}{ Panel C: Fix ed Income mutual funds } \\
\hline Brokerage Firms & $-1,633$ & $-0,628$ & $-0,055$ & $-0,004$ \\
\hline Inve stment Trusts & $-1,302$ & $-0,908$ & $-0,068$ & $-0,006$ \\
\hline Di? erence & $-0,331$ & 0,280 & 0,014 & 0,003 \\
\hline t-statistic & $-0,271$ & 0,895 & 1,131 & 1,205 \\
\hline $\begin{array}{l}\text { Number of BF out } \\
\text { performers }\end{array}$ & 7 & 1 & 1 & 9 \\
\hline $\begin{array}{l}\text { Number of IT out } \\
\text { performers }\end{array}$ & 7 & 2 & 2 & 6 \\
\hline
\end{tabular}

\footnotetext{
Notes: This table reports the performance of 146 mutual funds by investment type and fund manager from March 31, 1995 to June 30, 2016. Panel A presents the performance of mutual funds by fund manager, brokerage firms (BF) and investment trusts (IT). Panel B and C display mutual fund performance of mutual funds by investment type, equity and fixed income respectively, for each fund manager. The benchmarks for calculations are the MSCI index for the equity funds and the COLTES index for the fixed income funds. Figures are annualized. ${ }^{* * *} /{ }^{* *} / *$ indicate that with the paired $t$-test of means per measure, their difference is significantly different from zero at the $1 \% / 5 \% / 10 \%$ level. Source: Own elaboration.
}

Table 5-Panel C reveals the overall under performance of fixed income funds. Brokerage firm and investment trust funds yield risk-adjusted returns below the benchmarks, as evaluated by negative Sharpe ratios. Furthermore, there is no statistically significant difference in the underperformance of both type of managers. Similarly, the $M^{2}$ measure illustrates that risk-adjusted returns on brokerage firm and investment trust funds are 5 and 6 basis points lower than market returns respectively. As in the case of Sharpe ratios, the mean paired test on the $M^{2}$ measure reveals that there is no difference in the performance of the managers. Fixed income fund managers do not demonstrate superior investment skills. Jensen's alphas are negative for both type of managers. Moreover, the mean paired test on alphas indicate that, on average, brokerage firms and investment trusts do not statistically differ in their investment skills.

A closer examination on the investment skills of the managers is presented in Table 6, as assessed by the Sharpe ratio and Jensen's alpha. From the 146 funds in the sample, one exhibits a positive and statistically significant Sharpe ratio ${ }^{16}$, two funds evince superior skills, and 29 destroy value to investors, as reported through their alphas. In the equity market, Table 6-Panel B indicates that a brokerage firm fund displays a positive and statistically significant Sharpe ratio, and an investment trust fund generates alpha. Furthermore, three brokerage firm and two investment trust funds destroy value. In the bond market, Table 6-Panel C discloses that neither of the funds achieve returns in excess of the risk-free rate. The estimations performed in Equation 6 report that an investment trust fund exhibits superior investment abilities, and that 11 brokerage firm and 13 investment trust funds generate negative and statistically significant alphas. 
TABLE 6

Statistical significance on fund manager performance

\begin{tabular}{lllc}
\hline & \multicolumn{1}{c}{ Panel A: Total mutual funds } & Sharpe & Alpha \\
\hline \multirow{2}{*}{ Brokerage Firms } & Positive and statisticallysignificant & 1 & 0 \\
& Negative and statistically significant & 0 & 14 \\
\hline \multirow{2}{*}{ Investment Trusts } & $\begin{array}{l}\text { Positive and statisticallysignificant } \\
\text { Negative and statistically significant }\end{array}$ & 0 & 2 \\
& \multicolumn{1}{c}{ Panel B: Equitymutual funds } & & 15 \\
\multirow{2}{*}{ Brokerage Firms } & Positive and statistically significant & 1 & 0 \\
& Negative and statistically significant & 0 & 3 \\
\hline \multirow{2}{*}{ Investment Trusts } & Positive and statisticallysignificant & 0 & 1 \\
& Negative and statistically significant & 0 & 2 \\
& $\quad$ Panel C: Fix ed Income mutual funds & & \\
Brokerage Firms & Positive and statistically significant & 0 & 0 \\
& Negative and statistically significant & 0 & 11 \\
Investment Trusts & Positive and statisticallysignificant & 0 & 1 \\
& Negative and statistically significant & 0 & 13
\end{tabular}

\begin{abstract}
Notes: This table summarizes the number of mutual funds that exhibit statistically significant Sharpe ratios and alphas as measures of performance by investment type and fund manager. Panel A presents the overall performance of mutual funds by fund manager. Panel B and C displays the performance of mutual funds by investment type, equity and fixed income respectively, and by fund manager. Sharpe ratios and alphas are statistically significant at the $5 \%$ level. Sharpe ratios are statistically significant when Statistically significant alphas result from the estimation of Jensen's alpha. Source: Own elaboration.
\end{abstract}

To assess the relative performance of mutual fund managers via downside risk, we estimate the Sortino ratio, the Fouse index and the Upside potential ratio for the funds in the sample for three different DTRs as in previous sections. We present the measures and the non-parametric results of a mean paired test on the performance of the mutual funds in the sample by each measure in Table 7.

Table 7-Panel A reports the performance of mutual funds classified by manager. When the strategic objective of the fund is set to achieve positive risk-adjusted returns, both brokerage firm and investment trust funds do add value to investors. In this scenario, investment trust funds hand over higher risk-adjusted returns compared to their counterparts: specifically, 10 percentage points and 2 basis points according to the Sortino ratio and the Fouse index respectively. In addition, investment trust funds also display a higher potential to achieve positive returns.

Similar results are presented when the strategic return is the IPC. The Sortino ratio and the Fouse index reveal that investment trust funds outperform their peers by 39 and 3.5 basis points respectively. Nonetheless, the likelihood of brokerage firm funds to attain risk-adjusted returns above inflation per unit of downside deviation is 5,126 basis points greater than the UPR for investment trust funds.

Brokerage firm funds perform better when the investment objective is to beat the benchmark. The Sortino ratio discloses that neither of the funds outperform the market, in spite of the fact that brokerage firm funds generate 82 basis points in excess by unit of downside risk, compared to investment trust funds. With respect to the Fouse index, brokerage firm funds beat the market by one basis point and overcome investment trust funds by 3 basis points. Likewise, brokerage firm funds exhibit a higher probability to deliver returns above their benchmarks in relation to their peers, more precisely 45 basis points according to the UPR

In the equity market, Table 7-Panel B reports that managers provide positive risk-adjusted returns when the $D T R=0$, according to the Sortino ratio. Particularly, investment trust funds outperform their peers by 2 percentage points. Notwithstanding, brokerage firm funds display a greater ability to de-liver positive returns, as gauged by the UPR. Brokerage firm funds fail to yield risk-adjusted returns above inflation, by 15 and 4 basis points as reported by the Sortino ratio and the Fouse index respectively. The results for investment trust funds are mixed: while the Sortino ratio evinces that these funds outperform the strategic objective by 21 basis points, the Fouse index reveals that their risk-adjusted returns are 1 basis point below inflation. Nevertheless, the results on the mean paired test on the Sortino ratio suggest that investment trusts outperform brokerage firms as managers. However, the mean paired test on the Upside potential ratio reveals that brokerage firm funds display a greater ability to generate returns above inflation. As long as the investment objective is to outperform the equity benchmark, brokerage firm funds achieve this goal as anticipated by the Sortino ratio 
and the Fouse index, by 45 and 3 basis points respectively. On the other hand, the results on the performance of investment trust funds are positive for the Sortino ratio, while negative when the Fouse index is considered. Notwithstanding, the results on Table 7-Panel B disclose performance is not different for the managers.

TABLE 7

Fund manager performance, Downside measures

\begin{tabular}{|c|c|c|c|c|c|c|c|c|c|}
\hline \multirow{4}{*}{$\begin{array}{l}\text { Brokerage } \\
\text { Firms } \\
\text { Investment } \\
\text { Trusts }\end{array}$} & \multicolumn{3}{|c|}{$\mathrm{DTR}=0$} & \multicolumn{3}{|c|}{$\mathrm{DTR}=\mathrm{IPC}$} & \multicolumn{3}{|c|}{ DTR=BMK } \\
\hline & \multirow{2}{*}{$\begin{array}{r}\text { Sortino } \\
4,697\end{array}$} & \multirow{2}{*}{$\begin{array}{r}\text { Fouse } \\
0,015\end{array}$} & $\begin{array}{r}\text { UPR } \\
\text { Panel A }\end{array}$ & \multicolumn{2}{|c|}{$\begin{array}{l}\text { Sortino Fouse } \\
\text { Total mutual fund }\end{array}$} & UPR & \multirow{2}{*}{$\begin{array}{r}\text { Sortino } \\
-0,037\end{array}$} & \multirow{2}{*}{$\begin{array}{l}\text { Fouse } \\
0,008\end{array}$} & \multirow{2}{*}{$\begin{array}{l}\text { UPR } \\
7,265\end{array}$} \\
\hline & & & 9,551 & 0,124 & $-0,024$ & 5,890 & & & \\
\hline & 14,699 & 0,039 & 16,641 & 0,521 & 0,001 & 4,628 & $-0,863$ & $-0,030$ & 6,812 \\
\hline Di? erence & $.002 *$ & $0,024 * 4$ & $7.091 \%$ & $-0,396^{*}$ & 0,025 & $1,261^{* *}$ & $0,826^{4 * 4}$ & 0,0384 & $0,454^{* *}$ \\
\hline t-statistic & $-3,029$ & $-2,604$ & $-2,172$ & $-1,791$ & $-2,735$ & 2,560 & 5,564 & 3,034 & 2,045 \\
\hline $\begin{array}{l}\text { Number of BF } \\
\text { out performers }\end{array}$ & 56 & 43 & 37 & 45 & 43 & 27 & & 40 & \\
\hline $\begin{array}{l}\text { Number of IT } \\
\text { out performers }\end{array}$ & 45 & 8 & 22 & 18 & 8 & 11 & & 6 & \\
\hline \multicolumn{10}{|c|}{ Panal B: Equity mutual funds } \\
\hline $\begin{array}{l}\text { Brokerage } \\
\text { Firms }\end{array}$ & 0,553 & $-0,001$ & 7,147 & $-0,155$ & $-0,040$ & 6,671 & 0,458 & 0,032 & 7,927 \\
\hline $\begin{array}{l}\text { Investment } \\
\text { Trusts }\end{array}$ & 2,655 & 0,036 & 6,199 & 0,220 & $-0,006$ & 4,449 & 0,303 & $-0,001$ & 7,765 \\
\hline Di? erence & $-2,102 * *$ & $-0,037$ & $0,948^{*}$ & $-0,374^{*}$ & $-0,034$ & $2,2222^{* * *}$ & 0,156 & 0,033 & 0,163 \\
\hline t-statistic & $-3,382$ & $-1,540$ & 1,779 & $-1,706$ & $-1,459$ & 4,488 & 0,655 & 1,041 & 0,487 \\
\hline $\begin{array}{l}\text { Number of BF } \\
\text { out performers }\end{array}$ & 38 & 41 & 25 & 38 & 41 & 22 & & 38 & \\
\hline $\begin{array}{l}\text { Number of IT } \\
\text { out performers }\end{array}$ & 12 & 7 & 4 & 10 & 7 & 1 & & 5 & \\
\hline \multicolumn{10}{|c|}{ Panal C: Fixed income mutual funds } \\
\hline $\begin{array}{l}\text { Brokerage } \\
\text { Firms }\end{array}$ & 11916 & 0,043 & 13,738 & 0,611 & 0,005 & 4,528 & $-0,900$ & $-0,033$ & 6,112 \\
\hline $\begin{array}{l}\text { Investment } \\
\text { Trusts }\end{array}$ & 17,961 & 0,040 & 19,469 & 0,602 & 0,003 & 4,677 & $-1,179$ & $-0,038$ & 6,553 \\
\hline Di? erence & $-6,045$ & 0,003 & $-5,731$ & 0,009 & 0,002 & & $0,279 * 4 *$ & 0,005 & $-0,442^{*}$ \\
\hline t-statistic & $-1,024$ & 1,135 & $-0,960$ & 0,023 & 0,699 & $-0,181$ & 2,699 & 1,322 & $-1,719$ \\
\hline $\begin{array}{l}\text { Number of } B F \\
\text { out performers }\end{array}$ & 18 & 2 & 12 & 7 & 2 & 5 & & 2 & \\
\hline $\begin{array}{l}\text { Number of IT } \\
\text { out performers }\end{array}$ & 33 & 1 & 18 & 8 & 1 & 10 & & 1 & \\
\hline
\end{tabular}

Notes: This table reports the performance of 146 mutual funds by investment type and fund manager from March 31, 1995 to June 30, 2016, by means of the Sortino ratio, the Fouse index and the Upside potential ratio. Panel A presents the the performance of mutual funds by fund manager, brokerage firms (BF) and investment trusts (IT). Panel B and $\mathrm{C}$ display mutual fund performance of mutual funds by investment type, equity and fixed income respectively, for each fund manager. To estimate downside risk measures, three strategic return objectives (DTR) were considered: 0 ; annual inflation (IPC), and the annual mean return of the benchmark (BMK). The benchmarks for calculations are the MSCI index for the equity funds and the COLTES index for the fixed income funds. Figures are annualized. ${ }^{* * *} / * * / *$ indicate that with the paired t-test of means per measure, their difference is significantly different from zero at the $1 \% / 5 \% / 10 \%$ level.

Source: Own elaboration.

Table 7-Panel C presents evidence of the capability of the managers to generate positive risk-adjusted returns in the bond market, inasmuch as the Sortino ratio and the Fouse index are positive. Nonetheless, managers do not demonstrate different investment skills. Comparable results between funds are observed when the DTR equals inflation: fixed income managers deliver positive real returns to investors. Furthermore, the mean paired test on performance reveals that there is no difference in managerial skills. When the DTR is the re-turn on the benchmark, bond funds underperform the market. The mean paired test for the Sortino ratio indicates that brokerage firms exceed the performance of investment trust funds by 27 basis points per unit of downside deviation. On the other hand, investment trust funds procure a higher potential to outperform the market by 44 basis points.

\section{The "Hot Hand" phenomenon}

In the previous sections we analyzed mutual fund performance under the framework of the MPT and LPM measures, by type of investment and manager. In this section we address performance predictability, namely the ability of fund managers to continuously achieving superior returns. From the investors perspective, predictability of returns imply that they may consider to track the performance of a fund to invest in it.

Data in Table 8 show that winning funds tend to repeat their performance 58 percent of the time, from 2005 to 2015. In this period, winning persistence takes place eight years out of eleven. Similarly, there is 
evidence on losing persistence, thus the likelihood of a fund being a loser in the next period is greater when it is a loser in the current period. Furthermore, we find indication on negative persistence on three out of eleven years, this is when a currently winner (loser) fund was a loser (winner) in the previous year. For this period, six out of eleven years exhibit statistically significant persistence, but one out of eleven years displays negative significant persistence. Furthermore, we cannot reject the hypotheses of no winning persistence in four out of eleven years.

TABLE 8

Persistence of mutual fund performance

\begin{tabular}{|c|c|c|c|c|c|c|}
\hline & & & ear & & & \\
\hline Initial Year & & Loser & Winner & $\begin{array}{l}\text { Repeat } \\
\text { winners }\end{array}$ & Chi-Square & Z-Malkiel \\
\hline 2005 & Loser & 15 & 9 & $68,000 \%$ & 4,574 & 1,800 \\
\hline & Winner & 8 & 17 & & & \\
\hline 2006 & Loser & 16 & 9 & $57,692 \%$ & 2,407 & 0,784 \\
\hline & Winner & 11 & 15 & & & \\
\hline 2007 & Loser & 23 & 4 & $75,000 \%$ & 20,082 & 2,646 \\
\hline & Winner & 7 & 21 & & & \\
\hline 2008 & Loser & 20 & 10 & $83,333 \%$ & 15,429 & 3,651 \\
\hline & Winner & 5 & 25 & & & \\
\hline 2009 & Loser & 28 & 9 & $71,053 \%$ & 16,400 & 2,596 \\
\hline & Winner & 11 & 27 & & & \\
\hline 2010 & Loser & 26 & 20 & $60,870 \%$ & 2,788 & 1,474 \\
\hline & Winner & 18 & 28 & & & \\
\hline 2011 & Loser & 29 & 23 & $45,283 \%$ & 0,012 & $-0,687$ \\
\hline & Winner & 29 & 24 & & & \\
\hline 2012 & Loser & 26 & 37 & $41,270 \%$ & 3,841 & $-1,386$ \\
\hline & Winner & 37 & 26 & & & \\
\hline 2013 & Loser & 48 & 22 & $68,571 \%$ & 19,314 & 3,108 \\
\hline & Winner & 22 & 48 & & & \\
\hline 2014 & Loser & 47 & 26 & $64,384 \%$ & 12,082 & 2,458 \\
\hline & Winner & 26 & 47 & & & \\
\hline 2015 & Loser & 24 & 49 & $32,877 \%$ & 17,123 & $-2,926$ \\
\hline & Winner & 49 & 24 & & & \\
\hline $2005-2015$ & Loser & 302 & 218 & $57,524 \%$ & & \\
\hline & Winner & 223 & 302 & & & \\
\hline
\end{tabular}

\footnotetext{
Notes: This table presents two-way tables to test the persistence of mutual funds ranked by total returns from 2005 to 2015 , using annual intervals. Two statistics are reported to test fund persistence: Chi-square and Z-Malkiel. Statistical significance is $5 \%$. Source: Own elaboration.
}

When we examine persistence by investment type, Table 9 reports that 50 percent of the time, winner equity funds repeat their performance from 2012 to 2015. Nonetheless, equity mutual funds exhibit significant winning persistence two years out of four. Furthermore, we find statistical evidence on negative persistence for the rest of the period. On the other hand, Table 10 documents the positive persistence of bond funds returns. From 2008 to 2015, 70 percent of currently winner funds continue to achieve returns above the median fund return over the next year, thus bond funds consistently produce superior returns seven years out of eight.

TABLE 9

Persistence of equity mutual funds performance

\begin{tabular}{|c|c|c|c|c|c|c|}
\hline \multirow[b]{2}{*}{ Initial Year } & & \multicolumn{2}{|c|}{ Next Year } & \multirow[b]{2}{*}{$\begin{array}{l}\text { Repeat } \\
\text { winners }\end{array}$} & \multirow[b]{2}{*}{ Chi-Square } & \multirow[b]{2}{*}{ Z-Malkie } \\
\hline & & Loser & Winner & & & \\
\hline \multirow[t]{2}{*}{2012} & Loser & 8 & 17 & $32,000 \%$ & 6,480 & $-1,800$ \\
\hline & Winner & 17 & 8 & & & \\
\hline \multirow[t]{2}{*}{2013} & Loser & 22 & 9 & $71,875 \%$ & 11,564 & 2,475 \\
\hline & Winner & 9 & 23 & & & \\
\hline \multirow[t]{2}{*}{2014} & Loser & 23 & 10 & $70,588 \%$ & 10,873 & 2,401 \\
\hline & Winner & 10 & 24 & & & \\
\hline \multirow[t]{2}{*}{2015} & Loser & 7 & 26 & $23,529 \%$ & 20,458 & $-3,087$ \\
\hline & Winner & 26 & 8 & & & \\
\hline \multirow[t]{2}{*}{$2012-2015$} & Loser & 60 & 62 & $50,400 \%$ & & \\
\hline & Winner & 62 & 63 & & & \\
\hline
\end{tabular}

Notes: This table presents two-way tables to test the persistence of equity mutual funds ranked by total returns from 2012 to 2015 , using annual intervals. Two statistics are reported to test fund persistence: Chi-square and Z-Malkiel. Statistical significance is 5\%. 
TABLE 10

Persistence of fixed income funds performance

\begin{tabular}{|c|c|c|c|c|c|c|}
\hline \multirow[b]{2}{*}{ Initial Year } & & \multicolumn{2}{|c|}{ Next Year } & \multirow[b]{2}{*}{$\begin{array}{l}\text { Repeat } \\
\text { winners }\end{array}$} & \multirow[b]{2}{*}{ Chi-S quare } & \multirow[b]{2}{*}{ Z-Mallie } \\
\hline & & Loser & Winner & & & \\
\hline \multirow[t]{2}{*}{2008} & Loser & 13 & 8 & $86,364 \%$ & 10,714 & 3,411 \\
\hline & Winner & 3 & 19 & & & \\
\hline \multirow[t]{2}{*}{2009} & Loser & 15 & 13 & $60,714 \%$ & 1,149 & 1,134 \\
\hline & Winner & 11 & 17 & & & \\
\hline \multirow[t]{2}{*}{2010} & Loser & 23 & 8 & $71,875 \%$ & 13,371 & 2,475 \\
\hline & Winner & 9 & 23 & & & \\
\hline \multirow[t]{2}{*}{2011} & Loser & 25 & 8 & $73,529 \%$ & 16,276 & 2,744 \\
\hline & Winner & 9 & 25 & & & \\
\hline \multirow[t]{2}{*}{2012} & Loser & 24 & 14 & $63,158 \%$ & 5,263 & 1,622 \\
\hline & Winner & 14 & 24 & & & \\
\hline \multirow[t]{2}{*}{2013} & Loser & 27 & 11 & $71,795 \%$ & 14,137 & 2,722 \\
\hline & Winner & 11 & 28 & & & \\
\hline \multirow[t]{2}{*}{2014} & Loser & 27 & 12 & $70,000 \%$ & 12,159 & 2,530 \\
\hline & Winner & 12 & 28 & & & \\
\hline \multirow[t]{2}{*}{2015} & Loser & 28 & 11 & $72,500 \%$ & 15,500 & 2,846 \\
\hline & Winner & 11 & 29 & & & \\
\hline \multirow[t]{2}{*}{$2008-2015$} & Loser & 182 & 85 & $70,696 \%$ & & \\
\hline & Winner & 80 & 193 & & & \\
\hline
\end{tabular}

Notes: This table presents two-way tables to test the persistence of fixed income mutual funds ranked by total returns from 2008 to 2015 , using annual intervals. Two statistics are reported to test fund persistence: Chi-square and Z-Malkiel. Statistical significance is 5\%.

Source: Own elaboration.

A close analysis to the persistence of mutual funds returns by manager shows that brokerage firms funds do not display positive persistence. Table 11 reveals that these funds tend to be winners (losers) after being losers (winners) from one period to the other for three years out of six, from 2010 to 2015. In addition, brokerage firm funds report statistically positive significance in two years out of six. On the contrary, from 2009 to 2015, Table 12 presents that investment trusts funds consistently earn positive returns $2 / 3$ of the time. The null hypothesis of no winning persistence is rejected four years out of seven.

TABLE 11

Persistence of brokerage firm funds performance

\begin{tabular}{|c|c|c|c|c|c|c|}
\hline \multirow[b]{2}{*}{ Initial Year } & & \multicolumn{2}{|c|}{ Next Year } & \multirow[b]{2}{*}{$\begin{array}{c}\text { Repeat } \\
\text { winners }\end{array}$} & \multirow[b]{2}{*}{ Chi-Square } & \multirow[b]{2}{*}{ Z-Mallie } \\
\hline & & Loser & Winner & & & \\
\hline \multirow[t]{2}{*}{2010} & Loser & 4 & 17 & $33,333 \%$ & 9,722 & $-1,528$ \\
\hline & Winner & 14 & 7 & & & \\
\hline \multirow[t]{2}{*}{2011} & Loser & 5 & 20 & $6,897 \%$ & 29,719 & $-4,642$ \\
\hline & Winner & 27 & 2 & & & \\
\hline \multirow[t]{2}{*}{2012} & Loser & 6 & 27 & $17,647 \%$ & 27,590 & $-3,773$ \\
\hline & Winner & 28 & 6 & & & \\
\hline \multirow[t]{2}{*}{2013} & Loser & 28 & 11 & $72,500 \%$ & 15,500 & 2,846 \\
\hline & Winner & 11 & 29 & & & \\
\hline \multirow[t]{2}{*}{2014} & Loser & 28 & 14 & $67,442 \%$ & 9,889 & 2,287 \\
\hline & Winner & 14 & 29 & & & \\
\hline \multirow[t]{2}{*}{2015} & Loser & 5 & 37 & $13,953 \%$ & 46,725 & $-4,727$ \\
\hline & Winner & 37 & 6 & & & \\
\hline \multirow[t]{2}{*}{$2010-2015$} & Loser & 76 & 126 & $37,619 \%$ & & \\
\hline & Winner & 131 & 79 & & & \\
\hline
\end{tabular}

Notes: This table presents two-way tables to test the persistence of brokerage firm mutual funds ranked by total returns from 2010 to 2015, using annual intervals. Two statistics are reported to test fund persistence: Chi-square and Z-Malkiel. Statistical significance is 5\%.

Source: Own elaboration. 
TABLE 12

Persistence of investment trust funds performance

\begin{tabular}{|c|c|c|c|c|c|c|}
\hline \multirow[b]{2}{*}{ Initial Year } & & \multicolumn{2}{|c|}{ Next Year } & \multirow[b]{2}{*}{$\begin{array}{c}\text { Repeat } \\
\text { winners }\end{array}$} & & \multirow[b]{2}{*}{ Z-Malkie } \\
\hline & & Loser & Winner & & & \\
\hline \multirow[t]{2}{*}{2009} & Loser & 12 & 10 & $56,522 \%$ & 0,551 & 0,626 \\
\hline & Winner & 10 & 13 & & & \\
\hline \multirow[t]{2}{*}{2010} & Loser & 17 & 8 & $72,000 \%$ & 8,013 & 2,200 \\
\hline & Winner & 7 & 18 & & & \\
\hline \multirow[t]{2}{*}{2011} & Loser & 17 & 8 & $69,231 \%$ & 7,069 & 1,961 \\
\hline & Winner & 8 & 18 & & & \\
\hline \multirow[t]{2}{*}{2012} & Loser & 16 & 13 & $60,000 \%$ & 1,361 & 1,095 \\
\hline & Winner & 12 & 18 & & & \\
\hline \multirow[t]{2}{*}{2013} & Loser & 20 & 10 & $67,742 \%$ & 7,222 & 1,976 \\
\hline & Winner & 10 & 21 & & & \\
\hline \multirow[t]{2}{*}{2014} & Loser & 19 & 11 & $64,516 \%$ & 4,731 & 1,616 \\
\hline & Winner & 11 & 20 & & & \\
\hline \multirow[t]{2}{*}{2015} & Loser & 20 & 10 & $67,742 \%$ & 7,222 & 1,976 \\
\hline & Winner & 10 & 21 & & & \\
\hline \multirow[t]{2}{*}{$2009-2015$} & Loser & 121 & 70 & $65,482 \%$ & & \\
\hline & Winner & 68 & 129 & & & \\
\hline
\end{tabular}

Notes: This table presents two-way tables to test the persistence of investment trust mutual funds ranked by total returns from 2009 to 2015, using annual intervals. Two statistics are reported to test fund persistence: Chi-square and Z-Malkiel. Statistical significance is $5 \%$. Source: Own elaboration.

The previous results hold when we adjust returns by risk ${ }^{17}$. In general, mutual funds display the same persistence patterns once we analyze alphas and the Fouse index for a $D T R=0$. Mutual funds do exhibit positive and negative persistence. Furthermore, when we classify mutual funds by investment type, equity mutual funds display negative and statistically significant return persistence. In addition, bond funds that achieve superior risk-adjusted returns continue to exhibit such pattern in the next period. When it comes to fund managers, brokerage firm funds do not exhibit persistence; on the other hand, investment trust funds display positive and statistically significant persistence.

\section{CONCLUSION}

To evaluate fund performance is critical to any investor that allocates part of her assets into mutual funds. This assessment allows to compare risk-adjusted returns across funds and relative to a benchmark. Furthermore, such evaluation provides elements to execute either passive investment strategies, such as investing in index funds or ETF's, or to actively manage portfolios to out per-form the benchmark. Similarly, the evaluation stage includes the investment goals of each investor, thus fund performance is also related to the ability of the managers to achieve such objectives, and whether such performance persists.

Our traditional performance evaluation presents evidence on the overall underperformance of mutual funds in Colombia. Our findings are consistent with market efficiency, since mutual funds do not outperform their benchmarks. Furthermore, our results suggest that mutual funds destroy value to investors, thus an investor is better off when investing in passive strategies. While our research closely relates to the results of Piedrahita (2012) and Monsalve and Arango (2016), our downside risk evaluation also illustrates that Colombian mutual funds deliver positive and real returns to investors.

The average underperformance of mutual funds is attributable mostly to bond funds as they consistently underperform the market, therefore investing in the fixed income benchmark is the alternative to investors to achieve their investment objectives. Bond funds undermine the ability of equity funds that outperform the market, even though the latter hand over negative real returns to investors.

While mutual funds underperform the market, a traditional performance analysis on managers discloses that brokerage firms outperform investment trusts by providing higher risk-adjusted returns. These results hold when we analyze the role of managers in the equity market. Similarly, we found no difference in performance between managers in the bond market. Nonetheless, a further look to downside risk reveals 
that investment trusts deliver higher real returns. This is particularly true for equity funds, where they outperform brokerage firms as managers. These results are twofold: With some exceptions brokerage firms deliver higher risk-adjusted returns relative to the market, and investment trusts perform better when the investment objective of investors is to attain real returns.

Investors may also analyze past performance for investing in mutual funds. Our results suggest that past returns on bond funds and investment trust managers are indicative of future performance, in particular, the predictability of positive returns from one year to the next one. Our analysis on risk-adjusted returns and downside risk confirms that the risk-adjusted performance of funds managed by investment trusts is anticipated due to significant persistence from year to year.

Our cross-sectional study on fund performance is non-parametric, thus we do not tackle the causes on under performance. For example, the difference on performance may be explained by timing (Treynor $\&$ Mazuy, 1966; Henriksson \& Merton, 1981; Andreu, Matallín-Sáez, \& Sarto, 2018); investment style (Sharpe, 1992); the characteristics of the securities within mutual funds (Kent, Grinblatt, Titman, \& Wermers, 1997); stock-picking talent, load fees, expenses and turnover (Wermers, 2002); portfolio holdings (Brinson \& Fachler, 1985; Grinblatt \& Titman, 1989a,1989b; Andreu et al., 2018); trading efficiency (Cici, Dahm, \& Kempf, 2018), and active management Grinold and Kahn (2000); Cremers and Petajisto (2009); Petajisto (2013); Crane and Crotty (2018). In this regard, besides the documentation of the relative performance of Colombian mutual funds, further parametric studies are needed to explore the causes and the differences of performance among funds.

The methodological approach to study fund persistence do not consider the cross-correlation of fund returns. Funds managed in a similar style may exhibit similar performance, thus persistence may occur at the cross-section. Furthermore, there are not enough funds per "investment style" in the sample to overcome returns correlation (Malkiel, 1995). While our study demonstrates the short-term persistence of those funds managed by investment trusts and bond funds, further studies are needed to explain whether such persistence may remain in the long-term (Wermers, 2003; Kosowski, Timmermann, Wermers, \& White, 2006). Similarly, future research may delve on investing characteristics such as momentum (Carhart, 1997; Wermers, 2003); managerial skills (Bollen \& Buse, 2004; Kosowski et al., 2006; Huij \& Verbeek, 2007), and fund inflows (Wermers, 2003), as variables to explain persistence.

In sum, we find that Colombian mutual funds underperform the market. Our results ultimately suggest that an investor may invest in passive instruments that mimic the returns of the benchmark, which have a higher likelihood to delivering real returns. Nevertheless, investors may prefer funds managed by brokerage firms as they have a greater probability to outperform the market. Similarly, investors may be better off by investing in funds managed by investment trusts if their investment objective is to beat inflation. Finally, investors may analyze past performance to choose the manager and the fund to invest in, given that positive returns persist in the short-term.

\section{Referencias}

Andreu, L., Matallín-Sáez, J. C., \& Sarto, J. L. (2018). Mutual fund performance attribution and market timing using portfolio holdings. International Review of Economics and Finance, 57, 1-18. https://doi.org/10.1016/j.iref.20 18.02 .003

Bawa, V. S. (1975). Optimal rules for ordering uncertain prospects. Journal of Financial Economics, 2(1), 95-121. htt ps://doi.org/10.1016/0304-405X(75)90025-2

Bawa, V. S., \& Lindenberg, E. B. (1977). Capital market equilibrium in a mean-lower partial moment framework. Journal of Financial Economics, 5(2), 189-200. https://doi.org/10.1016/0304-405X(77)90017-4

Blume, M., Crocket, G., \& Friend, I. (1970). Measurement of portfolio performance under uncertainty. American Economic Review, 60(4), 561-575. 
Bollen, N., \& Buse, J. (2004). Short-term persistence in mutual fund performance. The Review of Financial Studies, 18(2), 569-597. https://doi.org/10.1093/rfs/hhi007

Bookstaber, R., \& Clarke, R. (1985). Problems in evaluating the performance of portfolios with options. Financial Analysts Journal, 4(1), 48-64. https://doi.org/10.2469/faj.v41.n1.48

Brinson, G. P., \& Fachler, N. (1985). Measuring non-us equity portfolio performance. The Journal of Portfolio Management, 11 (3) 73-76. https://doi.org/10.3905/jpm.1985.409005

Carhart, M. (1997). On persistence of mutual fund performance. The Journal of Finance, 52(1), 57-81. https://doi.o $\mathrm{rg} / 10.1111 / \mathrm{j} .1540-6261.1997 . t b 03808 . x$

Cici, G., Dahm, L. K., \& Kempf, A. (2018). Trading efficiency of fund families: impact on fund performance and investment behavior. Journal of Banking and Finance, 88, 1-14. https://doi.org/10.1016/j.jbankfin.2017.11.004

Contreras, O., Stein, R., \& Vecino, C. (2015). Estrategia de inversión optimizando la relación rentabilidad-riesgo: evidencia en el mercado accionario colombiano. Estudios Gerenciales, 31(137), 383-392. https://doi.org/10.10 16/j.estger.2015.07.005

Crane, A. D., \& Crotty, K. (2018). Passive versus active fund performance: do index funds have skill? Journal of Financial and Quantitative Analysis, 53(1), 33-64. https://doi.org/10.1017/S0022109017000904

Cremers, K. J., \& Petajisto, A. (2009). How active is your fund manager? A new measure that predicts performance. The Review of Financial Studies, 22(9), 3329-3365. https://doi.org/10.1093/rfs/hhp057

Dubova, I. (2005). La validación y aplicabilidad de la teoría de portafolio en el caso colombiano. Cuadernos de Administración, 18(30), 241-279.

Fama, E. (1970). Efficient capital markets: A review of theory and empirical work. The Journal of Finance, 25(2), 383-417. https://doi.org/10.2307/2325486

Fama, E., \& French, K. (1993). Common risk factors in the returns on stocks and bonds. Journal of Financial Economics, 33(1), 3-56. https://doi.org/10.1016/0304-405X(93)90023-5

Ferson, W., \& Siegel, A. (2001). The efficient use of conditioning information in portfolios. Journal of Finance, 56(3), 967-982. https://doi.org/10.1111/0022-1082.00351

Fishburn, P. (1977). Mean-risk analysis with risk associated with below-target returns. The American Economic Review, 67(2), 116-126. https://doi.org/10.2307/1807225

Goetzmann, W., \& Ibbotson, R. (1994). Do winners repeat? Journal of Portfolio Management, 20(2), 9-18. https:// doi.org/10.3905/jpm.1994.9

Goetzmann, W., Ingersoll, J., \& Ivkovich, Z. (2000). Monthly measurement of daily timers. Journal of Finance and Quantitative Analysis, 35(3), 257-290. https://doi.org/10.2307/2676204

Goetzmann, W., Ingersoll, J., Spiegel, M., \& Welch, I. (2007). Portfolio performance manipulation and manipulationproof performance measures. The Review of Financial Studies, 20(5), 1503-1546. https://doi.org/10.1093/rfs/ hhm 025

Grinblatt, M., \& Titman, S. (1989a). Mutual fund performance: An analysis of quarterly portfolio holdings. The Journal of Business, 62(3), 393-416. https://doi.org/10.1086/296468

Grinblatt, M., \& Titman, S. (1989b). Portfolio performance evaluation: Old issues and new insights. Review of Financial Studies, 2(3), 393-421. https://doi.org/10.1093/rfs/2.3.393

Grinold, R., \& Kahn, R. (2000). Active portfolio management. McGraw-Hill. https://doi.org/10.1002/9781119205 197.ch10

Henriksson, R., \& Merton, R. (1981). On market timing and investment performance. II. Statistical procedures for evaluating forecasting skills. The Journal of Business, 54(4), 513-533. https://doi.org/10.1086/296144

Huij, J., \& Verbeek, M. (2007). Cross-sectional learning and short-run persistence in mutual fund performance.Journal of Banking and Finance, 31(3), 973-997. https://doi.org/10.1016/j.jbankfin.2006.08.002

Jensen, M. (1968). The performance of mutual funds in the period 1945-1964. The Journal of Finance, 23(2), 389-416. https://doi.org/10.2307/2325404 
Kent, D., Grinblatt, M., Titman, S., \& Wermers, R. (1997). Measuring mutual fund performance with characteristicbased benchmarks. The Journal of Finance, 1035-1058.

Kosowski, R., Timmermann, A., Wermers, R., and White, H. (2006). Can mutual fund "stars" really pick stocks? New evidence from a bootstrap analysis. The Journal of Finance, 61(6), 2551-2595. https://doi.org/10.1111/j.1540 $-6261.2006 .01015 . x$

Lhabitant, F.-S. (2000). Derivatives in portfolio management: Why beating the markets is easy. Derivatives quarterly, 33(November), 1-18.

Lintner, J. (1965). The valuation of risk assets and the selection of risky investments in stock portfolios and capital budgets. The Review of Economics and Statistics, 51(2), 13-37. https://doi.org/10.2307/1926735

Malkiel, B. (1995). Returns from investing in equity mutual funds 1971 to 1991. The Journal of Finance, 50(2), 549-572. https://doi.org/10.1111/j.1540-6261.1995.tb04795.x

Markowitz, H. (1952). Portfolio selection. The Journal of Finance, 7(1), 77-91. https://doi.org/10.1111/j.1540-626 1.1952.tb01525.x

Medina, C., \& Echeverri, J. (1993). La selección de portafolios y la frontera eficiente: el caso de la Bolsa de Medellín, 1990-1992. Lecturas de Economía, 39, 103-149.

Modigliani, F., \& Modigliani, L. (1997). Risk-adjusted performance. The Journal of Portfolio Management, 45-54.

Monsalve, J., \& Arango, N. (2016). ¿Crean valor los fondos de inversión colectiva colombianos enfocados en acciones? Ecos de Economia, 20(42), 90-110. https://doi.org/10.17230/ecos.2016.42.5

Mossin, J. (1966). Equilibrium in a capital asset market. Econometrica, 34(4), 768-783. https://doi.org/10.2307/19 10098

Nawrocki, D. N. (1999). A brief history of downside risk measures. Journal of Investing, 8(3), 9-25. https://doi.org/ 10.3905/joi.1999.319365

Petajisto, A. (2013). Active share and mutual fund performance. Financial Analysts Journal, 69(4), 73-93. https://d oi.org/10.2469/faj.v69.n4.7

Piedrahita, A. (2012). Carteras colectivas en Colombia y las herramientas de medición para la generación de valor. Revista Civilizar, 3(6), 107-125. https://doi.org/10.22518/2462909x.242

Ramírez, G. (2012). La inversión colectiva en Colombia: caracterización y análisis. Soluciones de Postgrado EIA, 13-37.

Rom, B., \& Ferguson, K. (1993). Post-modern portfolio theory comes of age. Journal of Investing, 3(3), 11-17. https ://doi.org/10.3905/joi.3.3.11

Sharpe, W. (1964). Capital asset prices: A theory of market equilibrium under conditions of risk. The Journal of Finance, 19(3), 425-442. https://doi.org/10.1111/j.1540-6261.1964.tb02865.x

Sharpe, W. (1966). Mutual fund performance. The Journal of Business, 119-138.

Sharpe, W. (1992). Asset allocation: management style and performance evaluation. The Journal of Portfolio Management, 18(2), 7-19. https://doi.org/10.3905/jpm.1992.409394

Sortino, F. (1997). Looking only at return is risky, obscuring real goal. Pensions and Investments, 12.

Sortino, F. (2001). From alpha to omega. In F. Sortino \& S. Satchell (eds.), Economist (Vol. 372, pp. 63-64). Butterworth-Heinemann. https://doi.org/10.1016/b978-075064863-9.50002-5

Sortino, F., \& Price, L. (1994). Performance measurement in a downside risk framework. The Journal of Investing, 3(3), 59-64. https://doi.org/10.3905/joi.3.3.59

Sortino, F., \& van der Meer, R. (1991). Downside risk. Journal of Portfolio Management, 27-31.

Sortino, F., van der Meer, R., \& Plantinga, A. (1999). The dutch triangle. The Journal of Portfolio Management, 26(1), 50-57. https://doi.org/10.3905/jpm.1999.319775

Sortino, F., van der Meer, R., Plantinga, A., \& Kuan, B. (2010). Beyond the Sortino ratio. In Sortino, F. (ed.), The Sortino Framework for Constructing Portfolios (chapter 3, pp. 22-52). Elsevier.

Treynor, J. (1961). Toward a theory of market value of risky assets. In R. Korajczyk (ed.), Treynor on Institutional Investing (pp. 49-59). Risk Books. https://doi.org/10.1002/9781119196679.ch6 
Treynor, J. (1965). How to rate management of investment funds. Harvard Business Review, 63-75.

Treynor, J., \& Mazuy, K. (1966). Can mutual funds outguess the market? Harvard Business Review, 44(4), 131-136.

Wermers, R. (2002). Mutual fund performance: an empirical decomposition into stock-picking talent, style, transaction costs, and expenses. The Journal of Finance, 55(4), 1655-1695. https://doi.org/10.1111/0022-108 2.00263

Wermers, R. (2003). Is money really 'smart'? New evidence on the relation between mutual fund flows, manager behavior, and performance persistence. Available at SSRN: https://ssrn.com/abstract $=414420$ or http://dx.do i.org/10.2139/ssrn.414420.

\section{APPENDIX}

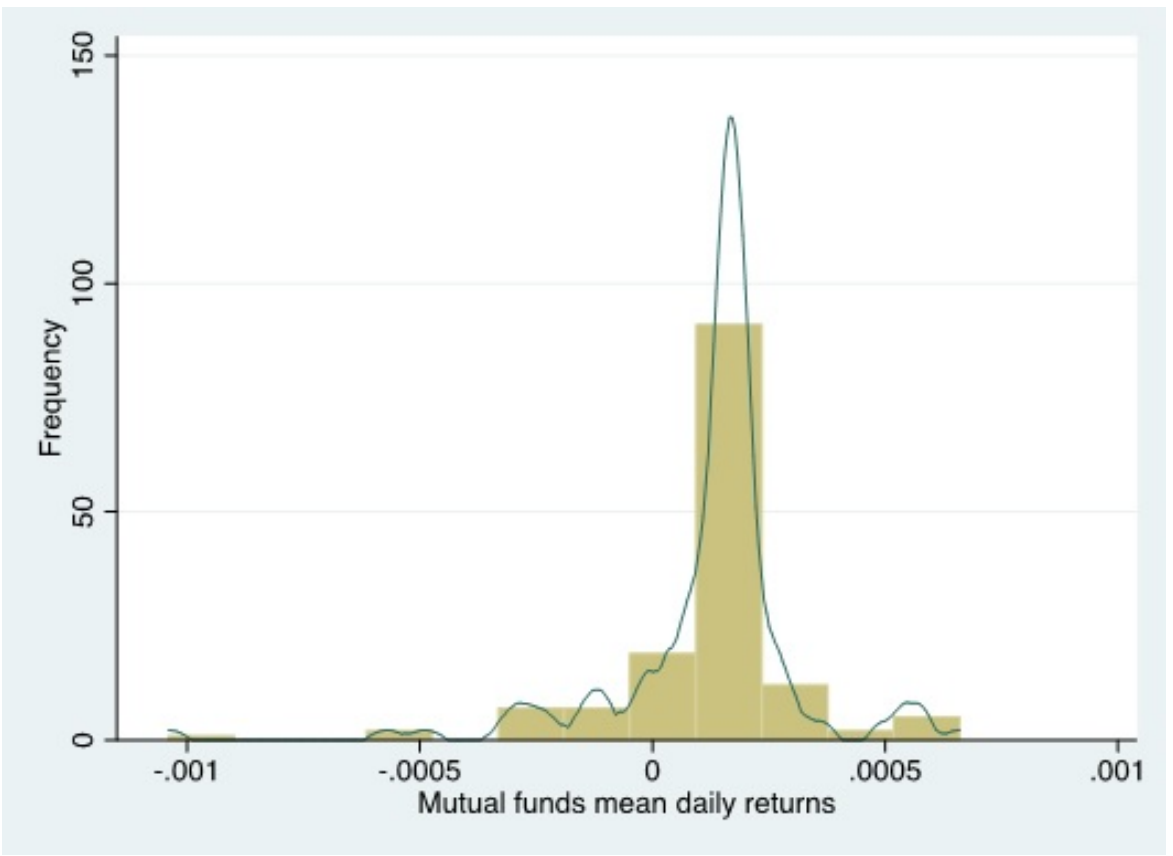

FIGURE 1

Mutual Funds returns

Note: This figure exhibits the Histogram (bars) and the Kernel Density plot (line) of the mean daily returns of 146 mutual funds. Daily returns are calculated as the change in NAV's. Source: Own elaboration. 


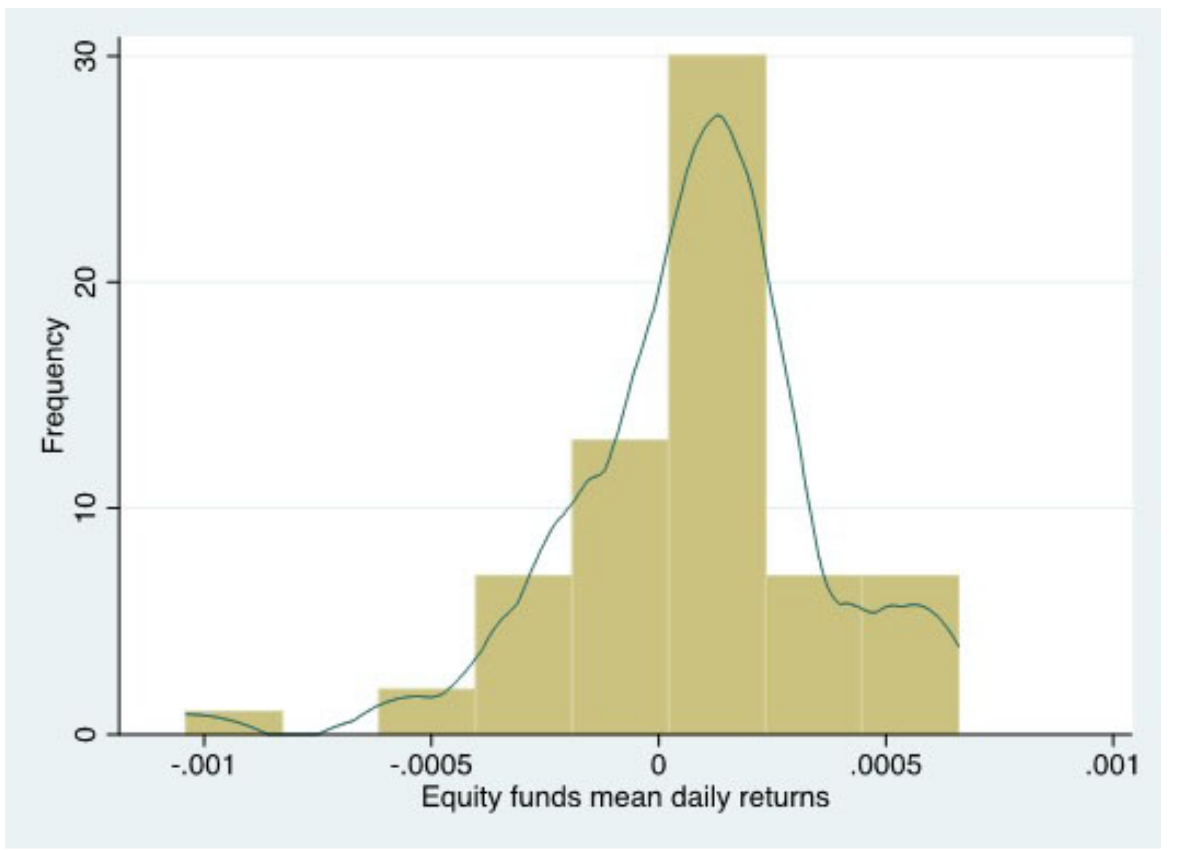

FIGURE 2

Equity Funds returns

Note: This figure presents the Histogram (bars) and the Kernel Density plot (line) of the mean daily returns of equity mutual funds. Daily returns are calculated as the change in NAV's. Source: Own elaboration.

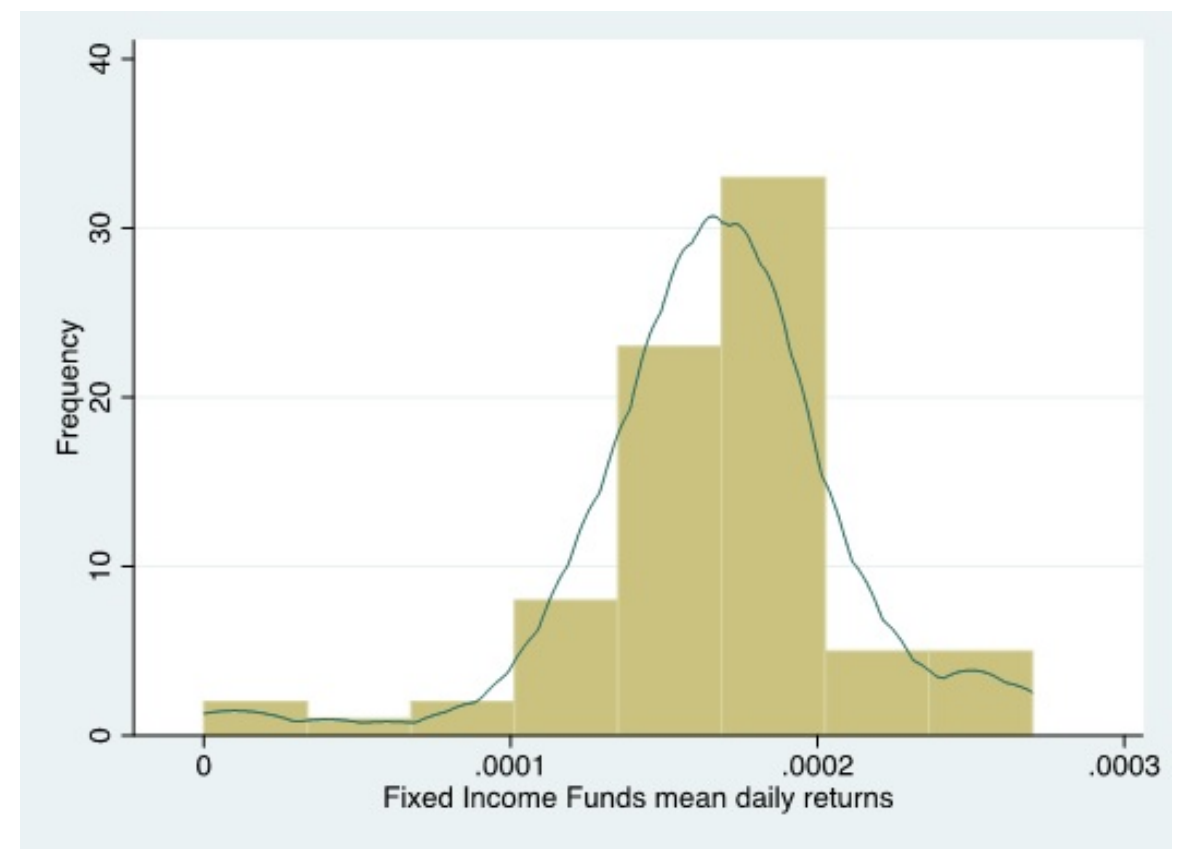

FIGURE 3

Fixed Income Funds returns

Note: This figure shows the Histogram (bars) and the Kernel Density plot (line) of the mean daily returns of fixed income mutual funds. Daily returns are calculated as the change in NAV'S. Source: Own elaboration. 


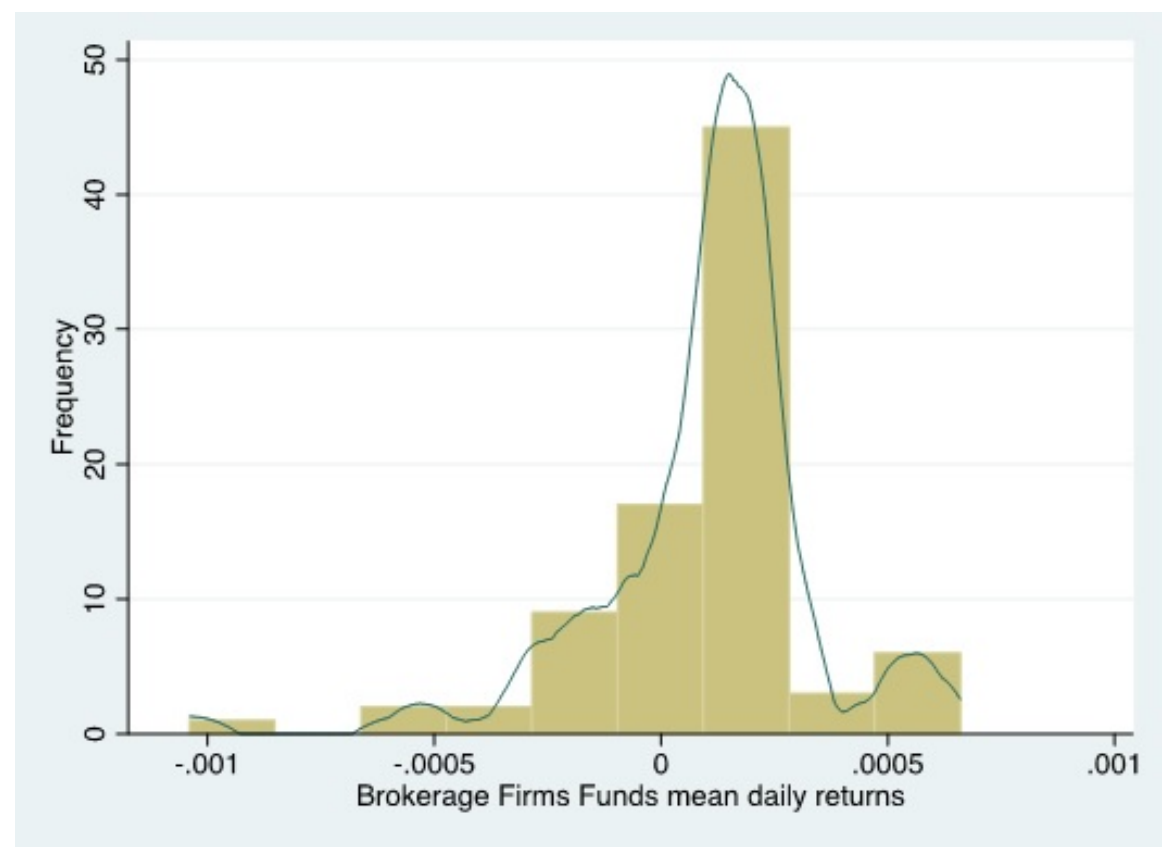

\section{FIGURE 4}

\section{Brokerage Firms Funds returns}

Note: This figure shows the Histogram (bars) and the Kernel Density plot (line) of the mean daily returns of mutual funds managed by Brokerage Firms. Daily returns are calculated as the change in NAV'S. Source: Own elaboration.

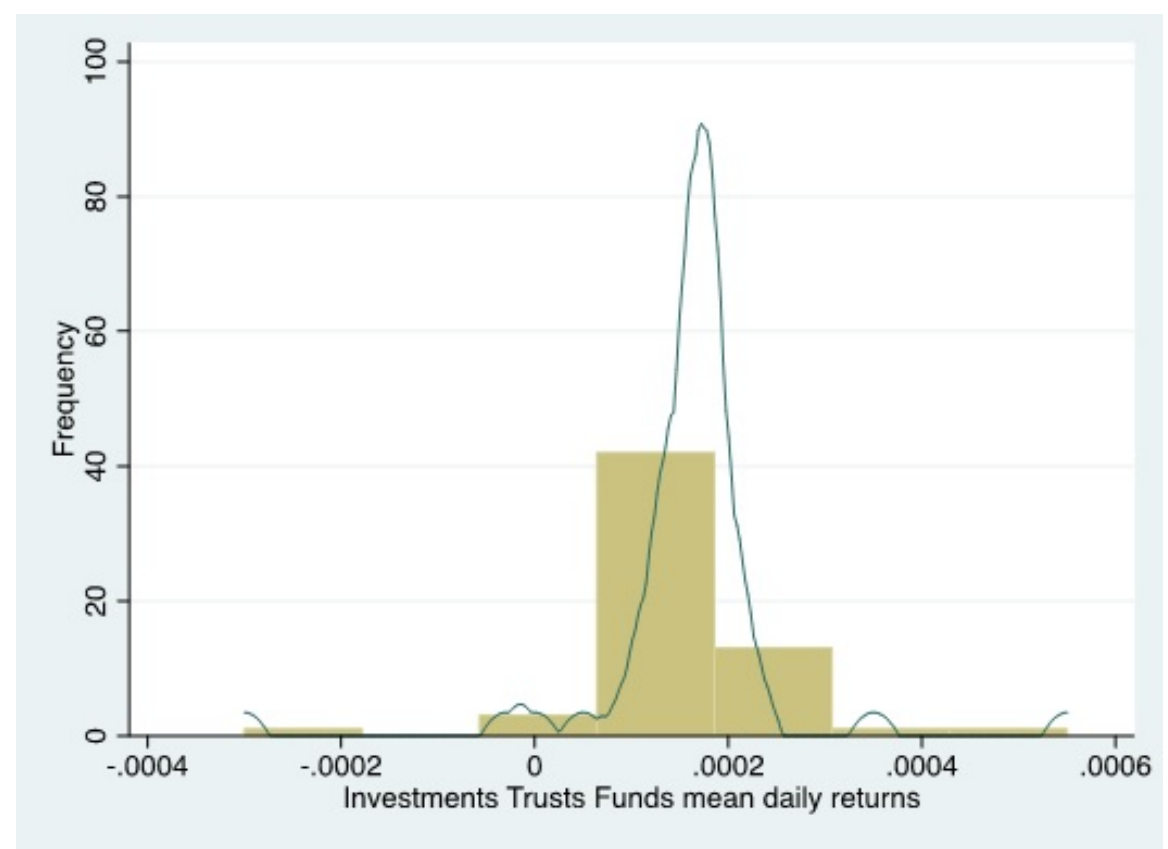

FIGURE 5

Investment Trusts Funds returns

Note: This figure shows the Histogram (bars) and the Kernel Density plot (line) of the mean daily returns of mutual funds managed by Investment Trusts. Daily returns are calculated as the change in NAV'S. Source: Own elaboration. 


\section{Licencia Creative Commons CC BY 4.0}

Cited as: Pulga V., F. A., \& Macías J., M. T. (2019). portfolio Managers on the Colombian Open-End Mutual Fund Industry: Performance, downside risk and persistence. Cuadernos de Administración, 32(59). DOI: h ttps://doi.org/10.11144/Javeriana.cao32-59.pmco

\section{Notes}

* Research paper.

1 Data collected from the Colombian regulator: Superintendencia Financiera de Colombia -SFC-.

2 Piedrahita (2012) utilizes the proprietary calculations of Fama and French (1993) for the US equity market.

3 We refer to bonds as fixed income securities.

4 For the purpose of this article, the upcoming discussion focuses on traditional performance ratios and downside risk measures. For portfolio analysis based on market timing see Treynor and Mazuy (1966) and Henriksson and Merton (1981). See Sharpe (1992) on style analysis. On performance based on portfolio holdings see Brinson and Fachler (1985), Grinblatt and Titman (1989a,1989b) and Kent et al. (1997).

5 This is achieved by constructing a risk-adjusted portfolio which holds both, the investment fund and risk-free assets. By changing the asset mix in a specific proportion, either leveraging or deleveraging, this new portfolio exhibits a standard deviation matched to that of the market portfolio and its expected return vary in such percentage.

6 Mean-lower partial variance is concerned on the dispersion of a probability function around a "target" value. In terms of risk, this measure refers to the dispersion of those values below the target. The lower partial moment is "a general family of below-target risk measures (one of them below-target semi variance)" (Nawrocki, 1999).

7 Sortino (2001) asserts that Fishburn's risk measure is concerned on the probability of not achieving a target return and also measures how far actual returns fall down below such target, thus risk in Fishburn's framework captures the magnitude and the probability of failure by including the complete set of returns. This function, known as downside variance, when the risk aversion factor is 2 , is not semi variance. Moreover, semi variance is a particular case of this function when the return distribution is symmetrical, and the target return is equal to the mean. Thus, MPT optimization is a special case of LPM (Rom \& Ferguson, 1993).

8 From 2003 to 2016, the average size of the Colombian capital market measured by traded value (fixed income and equity securities) is COP 2.55 billion per year. During this period, the bond market accounts for 98.5 percent of the total traded value. These figures are calculated using data collected from the SFC.

9 These results are statistically significant at a $0.01 \%$ significance level. The results are available upon request.

10 Betas are estimated through unrestricted linear regressions as in equation 6.

11 Following the methodology of Sortino and Price (1994), we use in this study a risk aversion factor equal to one.

12 With regards to the performance measures of previous section, we calculated them using both, the downside risk measure from the LPM literature (Equation 11) and the alternative measure (Equation 12). Even though both methodologies yield the same results, in the next section, we present the analysis based on the downside risk measure derived from lower partial moments. These results are available upon request.

13 Malkiel (1995) presents a binomial test to examine whether a fund displays a winning probability greater than 0.5 . The null hypothesis of the test is that this probability is equal to 0.5 . The Z-Malkiel statistic follows a standard normal distribution. 
14 From the CAPM regression, the t-statistic measures the statistical significance of alpha. Assuming normality on residual returns, a t-statistic greater than two indicates that alpha is significantly different from zero and that the performance of the portfolio is due to managerial skill, when the residual return is positive.

15 On choosing the "desired target return", Sortino (1997) provides an explanation on the relationship between the investment objectives and the required returns to achieve them. For example, whether the objective is to fund retirement, to beat inflation or to beat a benchmark, there will be a target return to accomplish such goals.

16 Grinold and Kahn (2000) present the statistical approach to analyze the significance of Sharpe ratios. A fund manager exhibits investment skills at a $95 \%$ confidence level when

17 Results available upon request. 